\title{
The Storm and Flood of September 15, 1989, in Fayetteville, North Carolina
}

By Robert R. Mason, Jr., and William S. Caldwell

U.S. GEOLOGICAL SURVEY

Water-Resources Investigations Report 92-4097

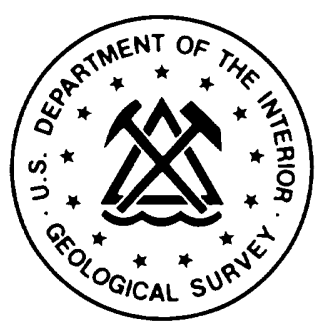

Prepared in cooperation with the

CITY OF FAYETTEVILLE, NORTH CAROLINA 


\section{U.S. DEPARTMENT OF THE INTERIOR}

MANUEL LUJAN, JR., Secretary

U.S. GEOLOGICAL SURVEY

Dallas L. Peck, Director

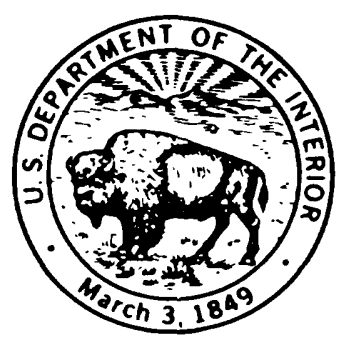

For additional information write to:

\section{District Chief}

U.S. Geological Survey

3916 Sunset Ridge Road

Raleigh, North Carolina 27607
Copies of this report can

be purchased from:

U.S. Geological Survey

Books and Open-File Reports Section

Federal Center, Box 25425

Denver, Colorado 80225 


\section{CONTENTS}

\section{FRONTISPIECE}

Night-time evacuation of residents from an extended heal th care facility during the flood of September 15, 1989, in Fayetteville, North Carolina.

\section{Abstract 1 \\ Introduction 1 \\ Purpose and scope 1 \\ Acknowledgments 3 \\ Description of study area 3 \\ Data collection 4 \\ Network data 4 \\ Post-flood data 4 \\ Basin-characteristics 5}

The storm and flood of September 15, 19896

Antecedent conditions 6

The storm 6

The flood 8

Attenuation effect of reservoirs 9

Flood profiles 10

Flood-inundation maps 12

Rainfall-intensity and flood-peak frequencies 14

Summary 19

References 19

Appendixes

1. Elevations, locations, and descriptions of high-water marks that resulted from the flood of September 15, 198922

2. Locations, distances upstream from mouth, and elevations of bridges, culverts, channels, and dams following the flood of September 15, 198925

\section{PLATE}

1. Map showing major geographic features and data-collection sites around Fayetteville, North Carolina, for flood of September 15, 1989. [In pocket]

\section{FIGURES}

1. Map showing location of Fayetteville in the Coastal Plain Province of North Carolina 2

2. Graphs showing rainfall and discharge at selected monitoring sites at Fayetteville, North Carolina, September 15-16, 19898

3-9. Cross sections showing streambed and 100-year flood profiles along:

3. Blounts Creek with bridge and high-water mark elevations for flood of September 15, 198911 
4. Branson Creek and Hybarts Branch with bridge and high-water mark elevations for flood of September 15, 198912

5. Cross Creek with bridge and high-water mark elevations for flood of September 15, 198913

6. Little Cross Creek with bridge and high-water mark elevations for flood of September 15, 198914

7. Big Cross Creek with bridge and high-water mark elevations for flood of September 15, 198915

8. Country Club Branch with bridge and high-water mark elevations for flood of September 15, 198916

9. Eutaw Creek with bridge and high-water mark elevations for flood of September 15, 198917

10. Graph showing rainfall-intensity frequency curves for selected recurrence intervals and maximum observed rainfall totals for selected durations for storm of September 15, 1989, at Fayetteville, North Carolina 18

\section{TABLES}

1. Basin characteristics at stream-gaging sites during flood of September 15,1989 , in Fayetteville, North Carolina 5

2. Maximum rainfall totals for selected durations for the storm of September 15, 1989, at Fayetteville, North Carolina 8

3. Peak discharges and estimated flood-frequency distribution for stream-gaging sites in Fayetteville, North

Carolina, on September 15, 19899

CONVERSION FACTORS AND VERTICAL DATUM

\begin{tabular}{|c|c|c|}
\hline Multiply & By & To obtain \\
\hline \multicolumn{3}{|c|}{ Length } \\
\hline inch (in.) & 25.4 & millimeter \\
\hline foot (ft) & 0.3048 & meter \\
\hline mile (mi) & 1.609 & kilometer \\
\hline \multicolumn{3}{|c|}{ Area } \\
\hline acre & 4,047 & square meter \\
\hline square mile $\left(\mathrm{mi}^{2}\right)$ & 2.590 & square kilometer \\
\hline \multicolumn{3}{|c|}{ Volume } \\
\hline cubic foot $\left(\mathrm{ft}^{3}\right)$ & 0.02832 & cubic meter \\
\hline acre-foot (acre-ft) & 1,233 & cubic meter \\
\hline \multicolumn{3}{|c|}{$\underline{\text { Flow }}$} \\
\hline foot per second (ft/s) & 0.3048 & meter per second \\
\hline cubic foot per second $\left(\mathrm{ft}^{3} / \mathrm{s}\right)$ & 0.02832 & cubic meter per second \\
\hline cubic foot per second & 0.01093 & cubic meter per second \\
\hline $\begin{array}{l}\text { per square mile } \\
\left(\mathrm{ft}^{3} / \mathrm{s}\right) / \mathrm{mi}^{2}\end{array}$ & & per square kilometer \\
\hline
\end{tabular}

Sea level: In this report "sea level" refers to the National Geodetic Vertical Datum of 1929 (NGVD of 1929)-a geodetic datum derived from a general adjustment of the first-order level nets of the United States and Canada, formerly called Sea Level Datum of 1929. 


\title{
The Storm and Flood of September 15, 1989, in Fayetteville, North Carolina
}

\author{
By Robert R. Mason, Jr., and William S. Caldwell
}

\section{ABSTRACT}

The storm of September 15, 1989, in and around the city of Fayetteville, North Carolina, produced the most extensive flooding of Fayetteville since 1945. The flood inundated 925 acres in the city along Cross Creek and Blounts Creek and their tributaries, flooded 338 buildings, caused damages in excess of $\$ 10$ million, and claimed the lives of 2 small children. Twenty-two roads and five earthen dams were overtopped. Three of the dams failed.

Recorded rainfall and streamflow data indicate that the storm and flood were relatively rare events. Recorded rainfall totals for durations of less than 2 hours were not exceptionally rare or unusual, but rainfall totals for 2-, 3-, and 6-hour durations recorded at a National Weather Service rain gage substantially exceeded 100-year rainfall amounts by approximately 31, 28, and 12 percent, respectively. Recorded unit-peak discharges ranged from 33 to 6,060 cubic feet per second per square mile, the latter downstream from a dam failure. Peak discharges at 6 of 10 stream-gaging sites had recurrence intervals greater than 100 years.

Flooding of Cross Creek and Blounts Creek upstream of Gillespie Street was generally less extensive than the 100-year flood, as delineated by the Federal Emergency Management Agency. Downstream of Gillespie Street, the flooding was more extensive.

\section{INTRODUCTION}

On Friday, September 15, 1989, a localized, violent, and intense cluster of thunderstorms stalled over the city of Fayetteville in south-eastern North Carolina (fig. 1). Intense rainfall, as much as 7.20 in. in 6 hours as recorded by the National Weather Service at site 11 (pl. 1), fell in parts of the city (National Oceanic and Atmospheric Administration, 1989b). The resulting runoff severed flashboard gates on Eutaw Pond dam (pl. 1), breached dams at Country Club Lake, Evans Lake, and Lockwood Pond (pl. 1), and initiated flash floods that struck much of the city without warning (Barrett, 1989). So sudden was the flooding that many travelers were stranded in their cars. In one instance, two small children drowned when they and five others tried to abandon their stalled vehicle in the midst of raging flood water triggered by the breaches of Evans Lake and Lockwood
Pond dams (Reese, 1989). Quickly rising water levels caught many residents of low-lying areas unaware and forced many of them to evacuate their homes late Friday night (September 15) or early Saturday morning (September 16).

By the time the flood water receded, 925 acres in the city along Cross and Blounts Creeks and their tributaries (pl. 1) had been inundated; millions of dollars in damages had been done to buildings, homes, roads, and bridges (Barrett, 1989). Repair and replacement costs of damaged streets, bridges, and culverts alone exceeded $\$ 10$ million (Jerry Croll, City of Fayetteville Engineering Department, oral commun., 1990).

The September 15, 1989, flood was the most extensive flood in Fayetteville since 1945. It differed from previous major floods in that most of the damaging floods in Fayetteville's history resulted from flooding of the Cape Fear River that inundated low-lying areas of the city (pl. 1); whereas, the September 15 flood originated from rain falling within the city or surrounding areas, and much of the damage was due to the failures of earthen dams.

The magnitude and frequency of floods are of concern to those who design, build, and maintain bridges, roads, and dams and to those who manage flood plains. Meteorologic and hydrologic data gathered during and after a notable flood, such as the one that occurred on September 15, 1989, can be useful in verifying or revising design criteria for structures, identifying flood-prone areas, and planning for floodmitigating actions. In response to these concerns, the U.S. Geological Survey, in cooperation with the city of Fayetteville, conducted a study to summarize meteorologic and hydrologic data collected during and after the storm and flood.

\section{Purpose and Scope}

This report documents the storm and flood of September 15, 1989, in Fayetteville, North Carolina. Specifically, the magnitude and frequency of storm rainfall and flood peak discharges are determined and inundated areas are delineated. The report also compares the September 15 flood elevations and inundated areas to those of the 100-year flood (Federal Emergency Management Agency, 1984). 


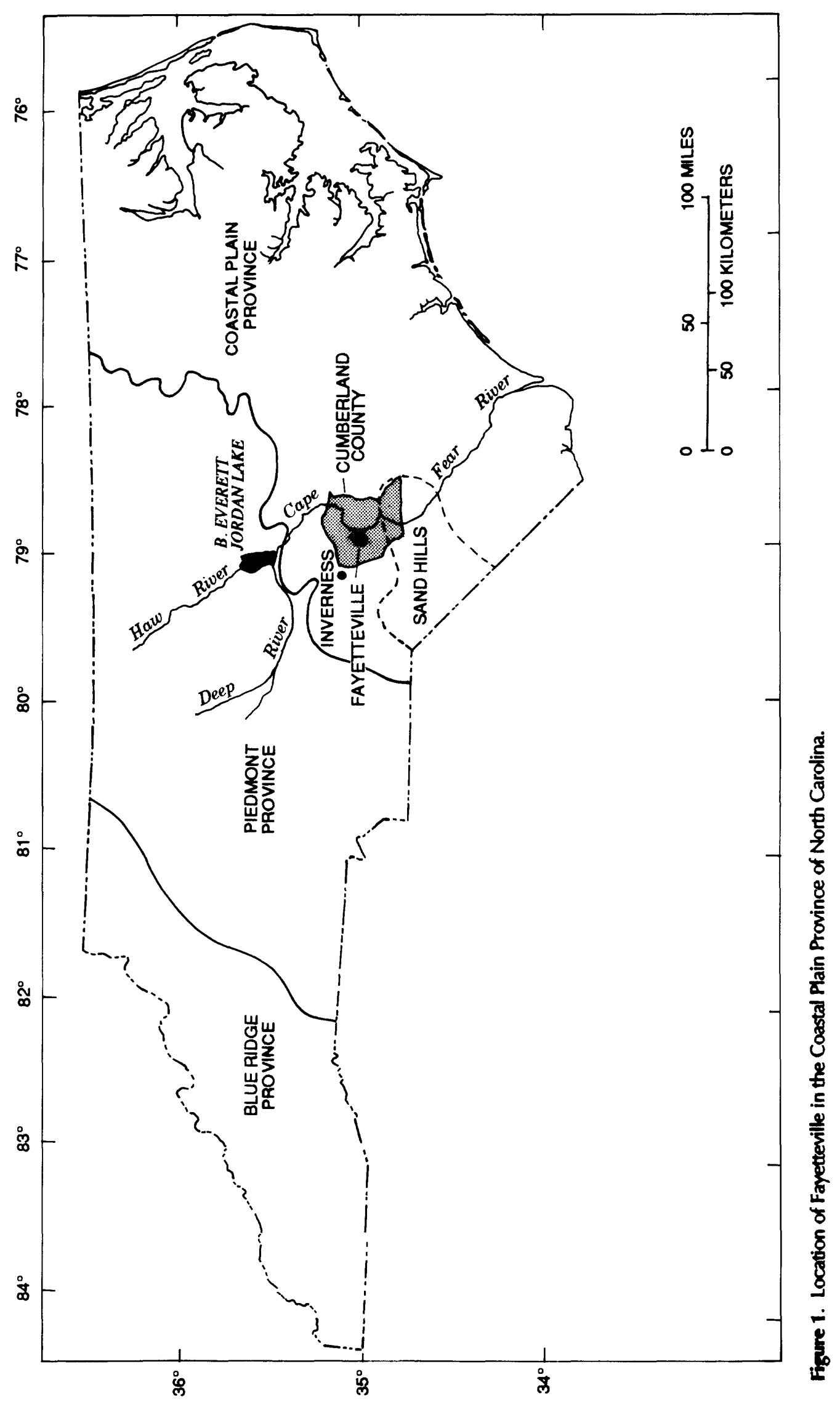


Stage and discharge data were collected at seven streamflow-gaging stations and at three miscellaneous measuring sites, and rainfall data were collected at three rainfall recording sites, all of which were used as the primary documentation for this study. Data from one long-term streamflow-gaging station were used to assess antecedent conditions. Observations of 117 high-water marks, and data collected at 57 bridges, culverts, or dams supplemented the primary data base. Standard analytical techniques were used to determine estimates of rainfall-intensity and peak discharge recurrence intervals.

\section{Acknowledgments}

The authors thank members of the Engineering Department, city of Fayetteville, for their assistance in conducting this study. The authors especially thank engineers Robert M. Bennett, Gerald F. Croll, and Gerald J. Howland who assisted in the planning and management of the study, and surveyors Paul R. Adams, Jr., Kenneth E. Hall, Stephen F. Jones, William R. Nichols, Joe Hales, Jr., and Selder F. Ashley who performed field surveys of high-water marks and bridge, culvert, and dam elevations. The authors also thank Sidney H. Post of the Fayetteville Public Works Commission who furnished stage-storage curves and spillway-design data for Bonnie Doone Lake.

\section{DESCRIPTION OF STUDY AREA}

The study area includes the city of Fayetteville and the surrounding area, primarily to the north and west of the city (pl. 1). Fayetteville lies on the west bank of the Cape Fear River near the eastern fringe of the Sand Hills region of North Carolina (fig. 1). The city covers an area of approximately 42 $\mathrm{mi}^{2}$ and has a population of 75,695 (U.S. Department of Commerce, 1991), a 27-percent increase over its 1980 population of 59,507. An additional 198,870 people live in adjacent areas of Cumberland County and on Fort Bragg Military Reservation and Pope Air Force Base northwest of Fayetteville.

Fayetteville is a major commercial center for several counties in the region. As the population has increased, the extent and density of urban developments within and around the city have rapidly increased as well, particularly around the northern and western limits of the city where several new shopping centers, suburbs, and apartment complexes have been built. Many of these developments drain stormwater into the headwaters of the principal streams, Blounts and Cross Creeks and their tributaries (pl. 1).

The topography of the Fayetteville area is characterized by large, relatively flat uplands, many of which are a mile or more across and separated from flood plains by steep-sloping scarps (pl. 1). Elevations range from $30 \mathrm{ft}$ above sea level at the Cape Fear River to more than $250 \mathrm{ft}$ in upland areas. The flat uplands and steep scarps are important determinants of runoff characteristics and channel capacities. Upstream of the scarps, areas adjacent to streams are poorly drained. Stream gradients are low, 1 percent or less, and channel capacities are low. As the streams pass through scarp areas, the stream gradients steepen, channels are more deeply incised, and channel capacities are greater.

The character of the soils also influences runoff characteristics. Fayetteville is included in a soil-systems transition zone at the intersection of the Sand Hills, Middle Coastal Plain, and Large Rivers soil-systems (Daniels and others, 1984). The most common soils in the Fayetteville area are Wagram and Faceville soils (Hudson, 1984, soil map number 11). These soils have a surface layer of grayishbrown, loamy sands about 7 in. thick and a subsurface layer of pale-brown, loamy sands about 10 in. thick. Wagram and Faceville soils are classified in Hydrologic Soil Groups Aand $B$, respectively, and have high- to moderate-infiltration capacities and low- to moderate-runoff potential (U.S. Department of Agriculture, 1972); light or moderate rainfall intensities rarely produce overland runoff with these soil types.

Small lakes and ponds in the area are a major influence on the flood hydrology of Fayetteville streams (pl. 1). These impoundments range in size from 1 to 80 acres and are formed by low earthen dams that are no more than $18 \mathrm{ft}$ high. The small ponds were originally constructed to supply water for field irrigation and livestock watering. The larger lakes were constructed to supply water for small milling operations and drinking water for the city of Fayetteville. None of the lakes were constructed to provide flood control; in most circumstances the normal water levels of the ponds are at or near their spillway elevations. However, the impoundments can attenuate flood water and reduce peak flows.

The nature and source of flooding problems in Fayetteville have changed in recent years. Prior to expanded urban development in and around the city, and construction in 1974 of B. Everett Jordan Dam and Lake in the Cape Fear River basin $55 \mathrm{mi}$ upstream of Fayetteville, major flooding of the city was due to flooding of the Cape Fear River and was limited mainly to low-lying areas east of Gillespie and Green Streets (pl. 1) (U.S. Army Corps of Engineers, 1970). However, as urban development has increased, so has the construction of parking lots, roads, buildings, and shopping centers. Large areas previously covered by highly pervious soils in fields and woodlands are now covered by impervious asphalt and concrete. Furthermore, large developments and highways are drained by extensive networks of stormwater sewers. These modifications have greatly increased flow velocities as well as total volumes of stormwater runoff, resulting in large increases in peak discharges. Because the principal streams of the city flow from newly developed areas in the northern and western sections to the south and east through older residential and business districts, the frequency 
and extent of nuisance flooding in established neighborhoods, even those rarely flooded 15 to 20 years ago, have increased in recent years (Jerry Croll, City of Fayetteville Engineering Department, oral commun., 1990).

Increased flooding of established neighborhoods following development activities in upstream areas is not unusual in a growing community, but might be more severe in the Sand Hills region than in adjacent areas. According to Gunter and others (1987), "Hydrologically, the Sand Hills are unique in North Carolina; storm runoff is considerably less here than that associated with other hydrologic areas because of the adsorbent nature of the sandy soils." Covering any soil with an impervious surface effectively reduces the infiltration capacity of that soil to zero. Because a greater relative decrease in infiltration exists for impervious areas covering sandy soils than for impervious areas covering clay or silty soils, the relative increase in stormwater runoff following urbanization of a small basin in the Fayetteville area is likely to be greater than the increase following urbanization of otherwise similar basins in the Piedmont or Coastal Plain Provinces. Therefore, the capacity of culverts, channels, or stormwater-drainage systems that were adequate prior to urbanization in the Fayetteville area are more likely to be exceeded following urbanization.

\section{DATA COLLECTION}

In February 1989, the U.S. Geological Survey (USGS), in cooperation with the city of Fayetteville and the North Carolina Department of Transportation, initiated a study to develop flood-frequency relations for urban areas throughout the State. As part of this investigation, the USGS established an urban rainfall-runoff monitoring network consisting of seven streamflow-gaging stations and seven rainfall recorders in and around the city of Fayetteville. The last station was installed a day before the flood. Information collected at these stations during the flood constitutes the primary data set for the analysis of the flood of September 15, 1989, in Fayetteville described in this report. The analysis of these data and preparation of this report were completed as part of a cooperative program with the city of Fayetteville.

Post-flood data were collected at three miscellaneous measurement sites, and numerous high-water marks were located and their elevations determined and recorded. Elevations of bridges, culverts, and dams were also measured. Analysis of the flood also required information relating to basin characteristics such as land-use patterns, drainage areas, impervious cover estimates, land slopes, and interbasin drainage diversions.

\section{Network Data}

The network gages are equipped with electronic data loggers to provide records of storm rainfall and runoff at either 5-minute or 1-minute intervals. In addition, stage data were collected on the Cape Fear River at Fayetteville (site 12, pl. 1) at hourly intervals as part of a separate, long-term monitoring network.

All of the network stream gages recorded data during the flood, but some data at Branson Creek at Murray Hill Road (site 6, pl. 1) were lost because of equipment failure.At Buckhead Creek at Coventry Road (site 5, pl. 1), flood water partly submerged the gage, but the recorder continued to operate throughout the flood. The actual peak stage and discharge for this site were determined by high-water marks.

The network stream-gaging sites meet criteria required for application of indirect methods for discharge measurements (Benson and Dalrymple, 1976). Culvert computations (Bodhaine, 1968), slope-area computations (Dalrymple and Benson, 1976), and weir and over-the-road flow computations (Hulsing, 1968) were used to determine discharges of the September 15 flood at the sites and to develop all stagedischarge ratings.

Most of the rain gages failed to record data completely through the storm. Problems were encountered at six rain gages because the equipment malfunctioned and because the capacity of the rain gages was exceeded.

In addition to the USGS rain gage network, the National Weather Service (formerly known as the U.S. Weather Bureau) operates a weighing bucket rain gage at site 11 (pl. 1). The gage is equipped with an analog-digital recorder that operates on a 15-minute recording interval. Data from this gage are cited in some discussions of the intensity and probable frequency of the storm in subsequent sections of this report.

\section{Post-Flood Data}

In addition to the network data, post-flood data were collected at several sites throughout the city. High-water marks and bridge and channel geometry were obtained to compute peak discharges at three peak-discharge measuring sites located at major stream crossings (sites 8,9, and 10, pl. 1) using indirect methods. These sites are downstream of breached dams and were selected as key locations for assessing the magnitude of the flood that inundated major sections of the city.

High-water marks also were flagged or staked along the major lengths of Hybarts Branch, Branson, Blounts, and Little and Big Cross Creeks and their tributaries (pl. 1) in the hours and days immediately following the flood. The threat of impending rains hastened the work and limited the extent and detail of flagging. In some cases, rain had distorted or 
obscured flood marks, but at least one mark was flagged upstream and downstream of most of the bridges, culverts, or dams along the creeks.

The elevations of the high-water marks (Appendix 1) and the elevations of the stream beds and the tops and bottoms of the bridges, culverts, roads, and dam spillways (Appendix 2) were established from field surveys and referenced to sea level using a citywide benchmark network. Information regarding the locations, elevations, and descriptions of the benchmarks was obtained from the Fayetteville City Engineering Department.

Some channel elevations along extensive reaches of the streams between bridges were determined from small-ratio scale city topographic maps $(1: 1,200$ or $1: 2,400)$ with 2 -ft contour intervals. Stream mileage from the mouth of the stream to the site of the high-water marks, bridges, culverts, and dams also was determined from city topographic maps.

\section{Basin Characteristics}

Regional flood-frequency relations (Sauer and others, 1983) were used to develop estimates of long-term flood-frequency distributions for the seven urban rainfall- runoff gaging stations and the three peak-flow measuring sites for comparison to the observed peak discharges of the September 15 flood. In order to use the relations, estimates were developed of the basin characteristics required for input to the flood-frequency relations. These characteristics included drainage areas, channel slopes, basin storages, impervious areas, basin-development factors, and frequency of rainfall intensity.

The study basins incorporate a broad range of urban land-use, topographic, and storm-drainage characteristics. Most of the basin characteristics for the urban rainfall-runoff sites in table 1 were determined from the city topographic maps previously described. Basin characteristics for the miscellaneous sites were developed from USGS topographic maps at the scale of 1:24,000. For the purpose of this study, contributing drainage areas were delineated on the topographic maps and the areas were planimetered.

In urban areas, stormwater is sometimes diverted across natural drainage divides by pipes, culverts, or manmade channels. In order to account for these diversions, the surface area of the subbasin where the stormwater originates is added to or subtracted from, as necessary, the area of the main basin.

Table 1. Basin-characteristics at stream-gaging sites during flood of September 15,1989 , in Fayetteville, North Carolina

[pl, plate; $\mathrm{mi}^{2}$, square mile; ft/mi, feet per mile]

\begin{tabular}{|c|c|c|c|c|c|c|c|}
\hline $\begin{array}{l}\text { Site } \\
\text { number } \\
\text { (pl. 1) }\end{array}$ & Name and location & $\begin{array}{c}\text { Contributing } \\
\text { drainage } \\
\text { area } \\
\left(\mathrm{mi}^{2}\right)\end{array}$ & $\begin{array}{l}\text { Main } \\
\text { channel } \\
\text { slope } \\
(\mathrm{ft} / \mathrm{mi})\end{array}$ & $\begin{array}{c}\text { Basin } \\
\text { storage } \\
\text { (percent) }\end{array}$ & $\begin{array}{c}\text { Total } \\
\text { impervious } \\
\text { area } \\
\text { (percent) }\end{array}$ & $\begin{array}{l}\text { Effective } \\
\text { impervious } \\
\text { area } \\
\text { (percent) }\end{array}$ & $\begin{array}{c}\text { Basin- } \\
\text { development } \\
\text { factor }\end{array}$ \\
\hline 1 & $\begin{array}{l}\text { Cape Fear River tributary } \\
\text { at Florida Drive }\end{array}$ & 0.04 & 375.0 & 0 & 12.0 & 0.30 & 4 \\
\hline 2 & $\begin{array}{l}\text { Little Cross Creek at } \\
\text { Bonnie Doone dam }\end{array}$ & 2.97 & 13.6 & 1 & 5.3 & .77 & 2 \\
\hline 3 & $\begin{array}{l}\text { Jack Fords Creek at } \\
\text { All American Freeway }\end{array}$ & .64 & 27.0 & 0 & 19.4 & 5.9 & 4 \\
\hline 4 & $\begin{array}{l}\text { Buckhead Creek at } \\
\text { Cliffdale Road }\end{array}$ & .82 & 19,9 & 0 & 48 & 41.0 & 11 \\
\hline 5 & $\begin{array}{l}\text { Buckhead Creek at } \\
\text { Coventry Road }\end{array}$ & 2.74 & 14.1 & 0 & 26.2 & 18.3 & 6 \\
\hline 6 & $\begin{array}{l}\text { Branson Creek at } \\
\text { Murray Hill Road }\end{array}$ & .64 & 29.5 & 0 & 27.0 & 25.4 & 8 \\
\hline 7 & $\begin{array}{l}\text { Hybarts Branch tributary } \\
\text { at Gunston Street }\end{array}$ & .10 & 174 & 0 & 23.0 & 14.3 & 10 \\
\hline a/ 8 & $\begin{array}{l}\text { Hybarts Branch at } \\
\text { Morganton Road }\end{array}$ & .99 & 29.3 & 2 & 17.9 & 4.6 & 8 \\
\hline$\underline{a} / 9$ & Cross Creek at Green Street & 26.4 & 10.2 & 2 & 13.1 & 2.7 & 6 \\
\hline$\underline{a} / 10$ & $\begin{array}{l}\text { Blounts Creek at } \\
\text { Gillespie Street }\end{array}$ & 10.7 & 27.2 & 1 & 16.4 & 2.8 & 5 \\
\hline
\end{tabular}

a/Miscellaneous measurement site. 
Main channel slope and basin storage also were determined from topographic maps. The main channel slope was measured between two points that are 10 and 85 percent, respectively, of the main channel length upstream of the gaging stations. Basin storage was determined by calculating the surface area of lakes, reservoirs, ponds, swamps, and wetlands shown on the maps. Temporary in-channel storage, such as ponding in detention basins or upstream from roadway embankments, was not included.

Field reconnaissance of the basins was conducted to locate prominent stormwater drainage features and to identify effective impervious cover in each basin. These features were added to the topographic maps. For purposes of this study, effective impervious cover is defined as that part of total impervious area hydraulically connected to receiving streams by pipes, drains, or sewers. The percentage of basin area that was totally impervious (buildings, roads, parking lots, and walkways) and the percentage of basin area that represented effective impervious cover were determined by using the grid-overlay method (Cochran, 1963). Three independent measurements of impervious areas were made at a minimum of 200 grid intersections for each basin; the maps were rotated 90 degrees between each measurement to ensure the independence of the three determinations. The three independent determinations were then averaged to obtain final percentages (table 1).

In addition to increases in impervious cover, alteration or development of drainage channels and of stormwatercollection systems substantially affects urban stormwater hydrology. To quantify these effects, a basin-development factor (BDF) was computed for each basin using the topographic maps that show the locations of major stormwater drainage features, such as storm gutters, street drains, culverts, and other channel improvements. The BDF includes evaluations of storm drains, channel improvements, and curbs and gutters. It is evaluated on a scale of zero to 12 , with zero indicating little or no development and 12 indicating a fully developed basin. The computation procedures are explained by Sauer and others (1983).

The last characteristic required for application of the regional flood-frequency relations is the 2-year, 2-hour rainfall. A value of 2.25 in. for the basins in the Fayetteville area was determined from the 2-year, 2-hour rainfall maps in U.S. Weather Bureau Technical Paper 40 (U.S. Department of Commerce, 1961).

\section{THE STORM AND FLOOD OF SEPTEMBER 15, 1989}

This section of the report discusses the chronology of the September 15, 1989, flood, including the hydrologic conditions that existed prior to the storm, storm rainfall intensity and duration, and the magnitude of the peak discharges. Flood profiles and inundation maps are described along with an analysis of rainfall intensity and flood frequency.

\section{Antecedent Conditions}

Although little rain fell in Fayetteville on the days just prior to September 15, 1989 (National Oceanic and Atmospheric Administration, 1989a), by most hydrologic measures the months preceding September were excessively wet. For the first 8 months of 1989, rainfall in Fayetteville was nearly $8.5 \mathrm{in}$. above normal and totaled $42.3 \mathrm{in}$. (National Oceanic and Atmospheric Administration, 1990).

At the long-term stream-gaging station nearest Fayetteville, Flat Creek near Inverness, N.C., located $15 \mathrm{mi}$ northwest of the city (fig. 1), streamflow was above normal from May to August; monthly discharges during this period were above the highest quartile of their respective monthly discharges for the period of record (1968-90). The monthly discharge for July 1989, $24.5 \mathrm{ft}^{3} / \mathrm{s}$ (Ragland and others, 1990), was the highest July discharge for the period of record, and the May, June, and August 1989 discharges were the second highest discharges for those months. These lengthy periods of above-normal rainfall and streamflow filled area lakes, ponds, and swamps to, or very near to, their capacities, thus reducing their ability to attenuate runoff from the September 15 storm.

\section{The Storm}

A combination of the presence of warm, moist, tropical air; afternoon convection heating; and a slow-moving cold front produced thunderstorm clusters over Fayetteville on the afternoon and evening of September 15, 1989 (Barnes, 1989). Brief rain showers began around 1245 hours and again at 1555 hours, lasting for about 20 minutes each (fig. 2). The thunderstorms weakened during the afternoon, but regenerated about 1730 hours with the approach of the cold front from the west. These thunderstorms were strengthened by a continuing flow of low-level tropical air. As the thunderstorms redeveloped, a cluster of them tracked slowly northward over the city before stalling around 1900 hours.

The most intense rainfall began at about 1730 hours and lasted until just after 2100 hours (fig. 2; table 2). During this period, nearly 7 in. of rain was recorded in the National Weather Service recording rain gage (site 11, pl. 1) (National Oceanic and Atmospheric Administration, 1989a). However, in some areas of Fayetteville, much more rain may have fallen. As much as 10 to 11 in. of rain was measured in unofficial, non-recording rain gages by residents near the Evans Lake and Lockwood Pond dams (pl. 1) from 1830 hours until 2230 hours (Carl Jordan, local resident and part owner of Evans Lake, oral commun., 1991). 

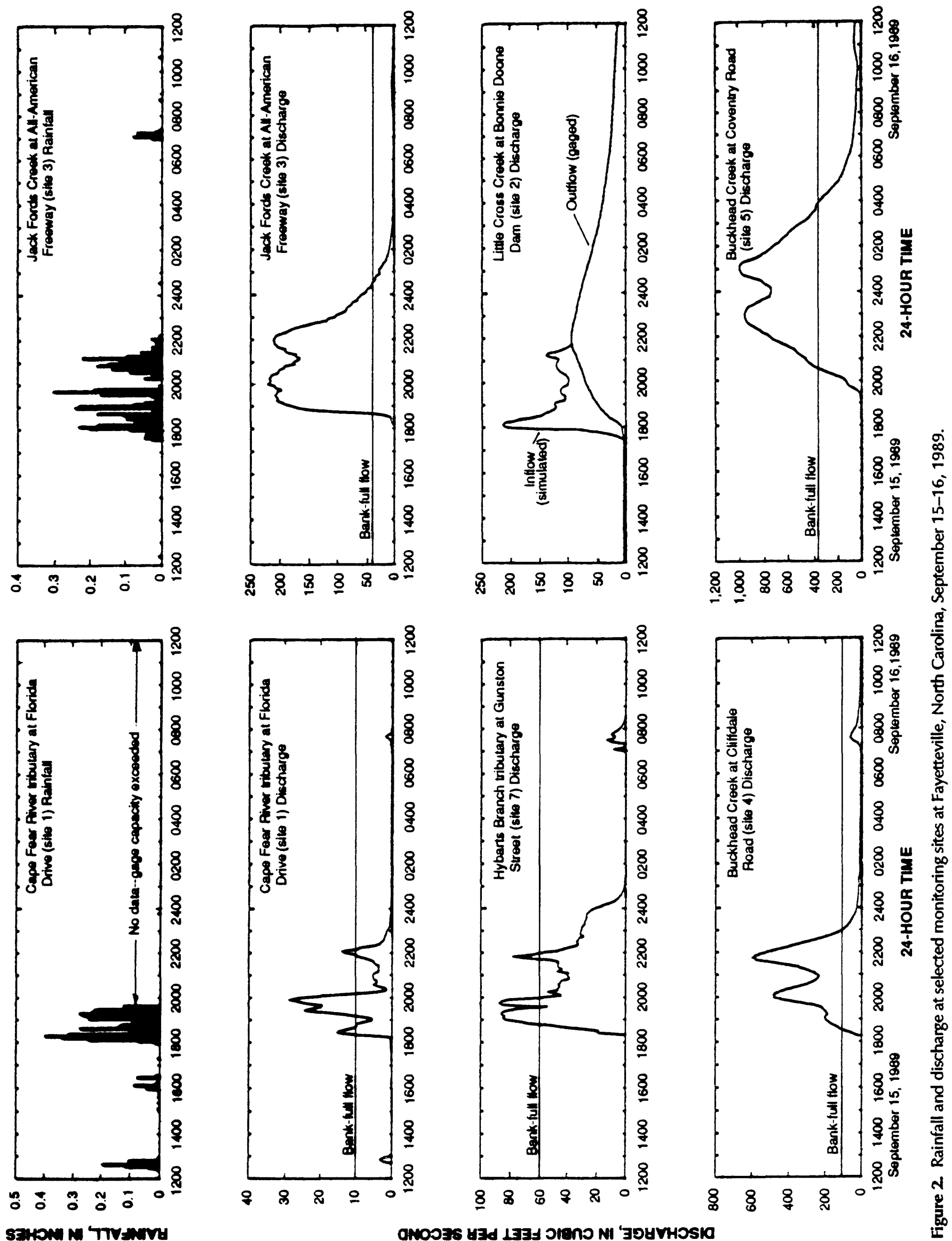
Table 2. Maximum rainfall totals for selected durations for the storm of September 15, 1989, at Fayetteville, North Carolina

[Site locations shown on plate 1 ; hr., hour; --, no data]

\begin{tabular}{|c|c|c|c|c|c|c|}
\hline \multirow[b]{2}{*}{ Duration } & \multicolumn{2}{|c|}{$\begin{array}{c}\text { Cape Fear River } \\
\text { tributary } \\
\text { (site 1) }\end{array}$} & \multicolumn{2}{|c|}{$\begin{array}{c}\text { Jack Fords } \\
\text { Creek } \\
\text { (site 3) }\end{array}$} & \multicolumn{2}{|c|}{$\begin{array}{l}\text { National Wegther } \\
\text { Service } \\
\text { (site 11) }\end{array}$} \\
\hline & $\begin{array}{c}\text { Rainfall } \\
\text { total } \\
\text { (inches) }\end{array}$ & $\begin{array}{l}\text { Measurement } \\
\text { ending time } \\
(24-\mathrm{hr} \text {. time })\end{array}$ & $\begin{array}{c}\text { Rainfal1 } \\
\text { total } \\
\text { (inches) }\end{array}$ & $\begin{array}{l}\text { Measurement } \\
\text { ending time } \\
(24-\mathrm{hr} \text {. time) }\end{array}$ & $\begin{array}{c}\text { Rainfall } \\
\text { total } \\
\text { (inches) }\end{array}$ & $\begin{array}{l}\text { Measurement } \\
\text { ending time } \\
(24-\mathrm{hr} \text {. time })\end{array}$ \\
\hline 5-minute & 0.40 & 1820 & 0.30 & 1945 & -- & -- \\
\hline 10-minute & .75 & 1820 & .49 & 1950 & -- & -- \\
\hline 15-minute & 1.06 & 1825 & .61 & 1950 & 1.70 & 1915 \\
\hline 30-minute & 1.51 & 1930 & .84 & 1930 & 2.30 & 1930 \\
\hline 1-hour & 2.50 & 1905 & 1.46 & 1950 & 3.30 & 1930 \\
\hline 2-hour & $\underline{b} / 4.11$ & 1940 & 2.79 & 1950 & 6.30 & 1945 \\
\hline 3-hour & -- & -- & 3.08 & 2030 & 6.80 & 2015 \\
\hline 6-hour & -- & -- & 4.61 & 2330 & 7.20 & 2315 \\
\hline 12-hour & -- & -- & 4.62 & 2400 & 7.20 & c / 0515 \\
\hline
\end{tabular}

\footnotetext{
a/Data from National Oceanic and Atmospheric Administration (1989b).

b/Actual 2-hour duration rainfall was greater than 4.11 inches, as the capacity of the rain gage was exceeded about 1 hour 40 minutes after the major rainfall began.

c/Date for this time is September 16, 1989.
}

As indicated by rainfall records collected at Cape Fear River tributary (site 1, fig. 2), rain fell nearly continuously for the first 2 hours of the storm. Between 1800 and 1900 hours, 2.25 in. of rain was recorded. A second downpour began at 1905 hours, dropping an additional measured 1.78 in. of rain until the capacity of the gage was exceeded at about 1940 hours. More rain fell after the last increment recorded by this gage, as indicated by records at the other two rain gages. At the National Weather Service station (site 11, pl. 1), for example, an additional $0.40 \mathrm{in}$. of rain was recorded after 2015 hours (National Oceanic and Atmospheric Administration, 1989b).

The greatest rainfall intensity during the storm, $6.8 \mathrm{in}$. per hour (1.7 in. in 15 minutes), was recorded at the National Weather Service rain gage (site 11). Rainfall totals measured during the storm at the three operational rain gages for 5-, 10-, 15-, and 30-minute and 1-, 2-, 3-, 6-, and 12-hour durations are summarized in table 2 , which also includes the ending times of each measurement period.

\section{The Flood}

Storm runoff began almost immediately following the onset of intense rains in the evening of September 15. Asteep rise in streamflow occurred at approximately 1830 hours at Cape Fear River tributary, Jack Fords Creek, Hybarts Branch tributary at Gunston Street, and Buckhead Creek at Cliffdale Road (sites 1, 3, 7, and 4, respectively, fig. 2). The rises continued briefly and discharge peaked quickly at most stream-gaging sites.

Discharge at Hybarts Branch tributary was the first to peak; a 5-minute interval recorder indicated that streamflow peaked at 1945 hours at $87 \mathrm{ft}^{3} / \mathrm{s}$ (fig. 2), but high-water marks left on the exterior of the gage indicated a higher peak flow of $100 \mathrm{ft}^{3} / \mathrm{s}$ (site 7, table 3). This apparent discrepancy in flow rates is indicative of the swiftness at which stages rise and fall during an event of this nature on a small urban stream; the peak discharge occurred and receded during the 5-minute period between consecutive recorder readings.

Across town, the Cape Fear River tributary discharge peaked 10 minutes later (1955 hours) at $29.8 \mathrm{ft}^{3} / \mathrm{s}$ (site 1 , table 3). Discharge at Buckhead Creek at Cliffdale Road peaked at 
Table 3. Peak discharges and estimated flood-frequency distribution for stream-gaging sites in Fayetteville, North Carolina, on September 15, 1989

[ft $\mathrm{ft}^{3} / \mathrm{s}$, cubic foot per second; $\left(\mathrm{ft}^{3} / \mathrm{s}\right) / \mathrm{mi}^{2}$, cubic foot per second per square mile]

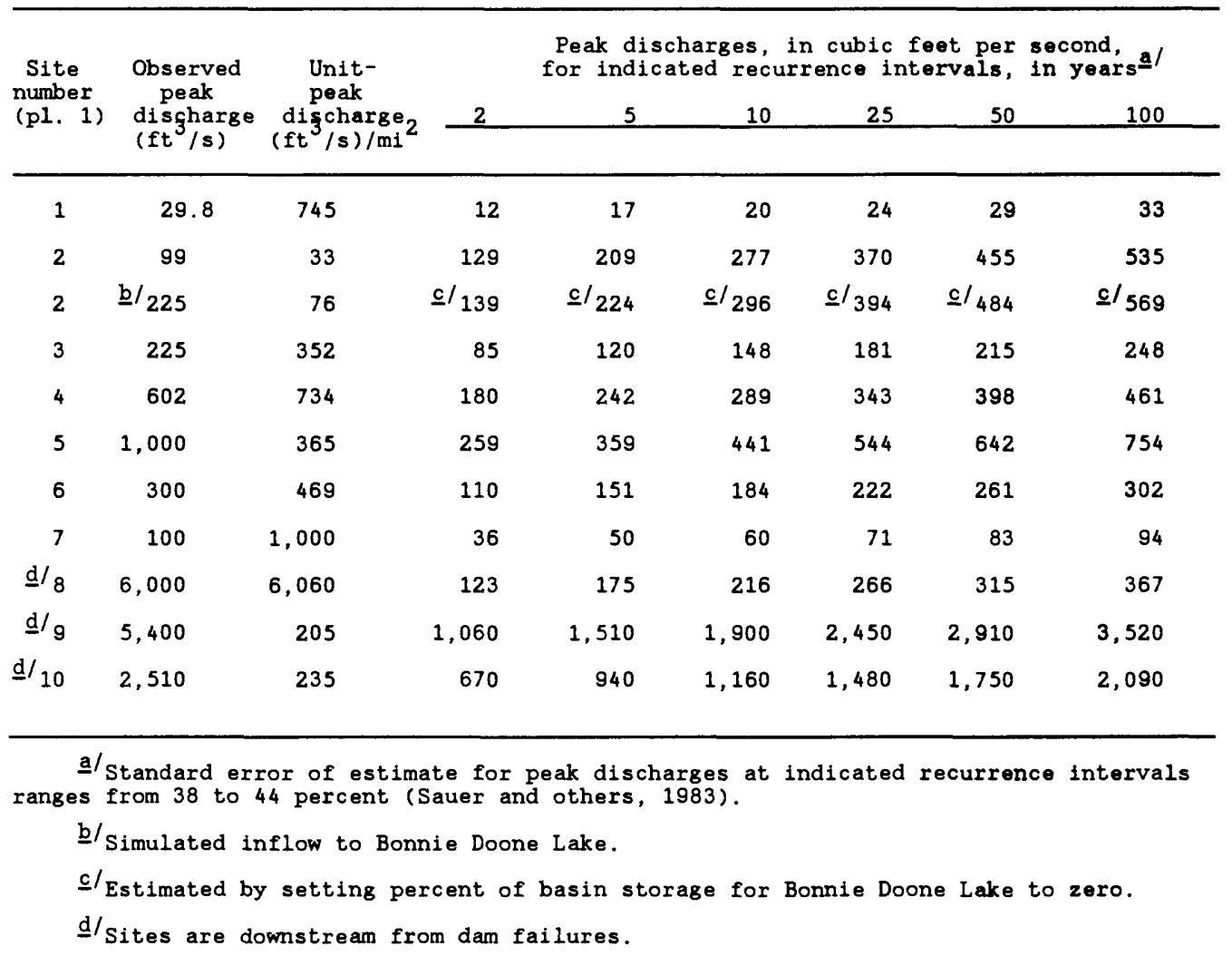

2145 hours at $602 \mathrm{ft}^{3} / \mathrm{s}$ (site 4, table 3). Discharge at larger streams peaked later. Little Cross Creek at Bonnie Doone Dam and Buckhead Creek at Coventry Road were the last of the gaged sites to peak at 2200 hours and at 0100 hours on September 16, respectively. The destination of the flood water was the Cape Fear River. The flood caused a total stage rise of $5.47 \mathrm{ft}$ at the Cape Fear River at Fayetteville (site 12, pl. 1), from $31.01 \mathrm{ft}$ at 1900 hours to $32.18 \mathrm{ft}$ an hour later, and peaking at $36.48 \mathrm{ft}$ at 0600 hours on Saturday, September 16.

Although many of the streams reached peak discharge early in the storm with discharges declining slightly thereafter, continuing rainfall sustained high runoff rates for many hours. At Buckhead Creek at Cliffdale Road, bank-full discharge continued for 4.5 hours; whereas, downstream at Coventry Road, bank-full discharge continued for more than 7 hours (fig. 2, sites 4 and 5, respectively). At Cross Creek at Green Street, site 9, flood water did not fall below bank-full level until early Sunday morning, September 17.

The effects of the storm and flood were limited to the immediate vicinity of Fayetteville. No rises in stage or discharge occurred at any of the stream gages on the Cape
Fear River upstream of Fayetteville, nor were any significant increases recorded at the stream-gaging station on Flat Creek at Inverness, N.C., northwest of Fayetteville.

\section{Attenuation Effect of Reservoirs}

During the flood, storm runoff filled several small ponds and lakes along Blounts, Branson, Big Cross, and Little Cross Creeks (pl. 1), and their tributaries as water flowed from upland areas to the Cape Fear River. The effect of this filling was to attenuate the flood by reducing peak discharges and delaying the onrush of flood water. An example of reservoir-induced attenuation is presented in figure 2 , which depicts the simultaneous inflow and outflow hydrographs of Bonnie Doone Lake at site 2. The inflow hydrograph was computed from lake stage and outflow data collected at site 2 using reservoir routing techniques (Viessman and others, 1977). Because of instabilities in mathematical computations, some smoothing and subdividing of the 5-minute interval lake-stage data were required, but the computed 
discharges were not greatly affected and are considered accurate to \pm 20 percent of their true values.

Based on computed inflow and measured outflow, the incoming flood water in Little Cross Creek was delayed by Bonnie Doone Lake, and the peak discharge at site 2 (fig. 2) was reduced from 225 to $99 \mathrm{ft}^{3} / \mathrm{s}$, a 56-percent reduction. A similar process was probably repeated at each lake downstream of Bonnie Doone Lake, delaying flood water and reducing downstream peak discharges on Little Cross Creek below values that might have occurred had the lakes been absent.

Peak-discharge attenuation also likely occurred along the other major streams that flowed through reservoirs. In instances where dams were breached and failed, however, the opposite was true; peak discharges were greatly increased as water was released suddenly creating, perhaps, several times the rate of flow that would have been expected from storm runoff alone. Failures of dams at Evans Lake, Lockwood Pond, and Country Club Lake (pl. 1) were caused by plug failure of earthen dams. The failure at Eutaw Pond (pl. 1) was caused by a breakup of flashboard gates.

Witnesses to the failure of Evans Lake Dam on Hybarts Branch say that water overtopped the 18 - $\mathrm{ft}$ high earthen dam at approximately 2030 hours (Jim Simons, North Carolina Department of Environment, Health, and Natural Resources, written commun., 1991). Water flowed 10 to 15 in. deep across the 200-ft long dam crest for about 1 hour before cutting a large gulley along the west end of the dam. This gulley quickly deepened and widened and led to a complete breach of the dam at about 2230 hours, releasing the contents of the 8-acre lake (John Paschal, local resident, oral commun., 1991). The lake was about $16 \mathrm{ft}$ deep and contained an estimated 50 acre-ft of water at its peak watersurface elevation (approximately $4 \mathrm{ft}$ above its normal pool elevation) when the breach occurred.

The breach of Evans Lake Dam set off a chain reaction as water rushed through it and into Lockwood Pond immediately downstream (pl. 1). This pond covered approximately 4.5 acres, was impounded by a $14-\mathrm{ft}$ earthen dam, and contained approximately 25 acre-ft of water. Shortly after the failure of the Evans Lake Dam, water began overflowing the Lockwood Pond Dam and continued to flow across the crest at a depth of $1 \mathrm{ft}$ for about one-half hour according to local residents (Jim Simons, North Carolina Department of Environment, Health, and Natural Resources, written commun., 1991). Gradual erosion of the dam eventually resulted in a 50 - $\mathrm{ft}$ wide breach.

The resulting unit-peak discharge in Hybarts Branch was $6,060\left(\mathrm{ft}^{3} / \mathrm{s}\right) / \mathrm{mi}^{2}$ at Morganton Road (site 8, pl. 1; table 3) about $300 \mathrm{ft}$ below Lockwood Pond Dam. This discharge was computed by combining over-the-road flow (Hulsing, 1968) and through-the-culvert flow (Bodhaine, 1968). The discharge at Morganton Road greatly exceeds the peak discharge expected had the dams remained intact. In contrast, at Hybarts Branch tributary at Gunston Street (site 7, pl. 1; table 3), less than a mile from Lockwood Pond, the unit-peak discharge was only $1,000\left(\mathrm{ft}^{3} / \mathrm{s}\right) / \mathrm{mi}^{2}$, even though the basin of Hybarts Branch tributary is more densely developed. About 23 percent of the area of Hybarts Branch tributary at Gunston Street (site 7) is covered with impervious surfaces, compared with 18 percent of Hybarts Branch basin above Morganton Road (site 8), and basin development factors are 10 and 8, respectively (table 1). Rainfall intensities upstream of Morganton Road (site 8) might have been greater, but it is unlikely that higher rates of rainfall alone would have caused six times the runoff yield at site 8 over that at site 7 .

\section{Flood Profiles}

Flood profiles may be used to assess the performance of hydraulic structures during the September 15 flood. Flood profiles for Blounts, Branson, and Cross Creeks (pl. 1) and their tributaries were constructed by plotting high-water mark elevations at bridges, culverts, dam tops, dam spillways, and stream beds against stream distances from the respective stream mouths (figs. 3-9). High-water mark elevations shown on the figures are strictly applicable only at the locations listed on the figures. The slopes between these known water-surface elevations need not be linear, nor do they necessarily parallel the slope of the stream beds.

The profiles (figs. 3-9) indicate that 22 roads and 5 dams were overtopped during the September 15 flood. Some roadways, such as Campbell Avenue (fig. 3), were completely inundated to the extent that, during the peak of the flood, they were impassable to vehicular traffic. Other structures conveyed the flood without flood water overtopping roads or emergency spillways. However, the structures that conveyed the flood without overtopping did so with varying degrees of clearance. The culvert on Blounts Creek at Gillespie Street (pl. 1), for example, conveyed the flood water at a peak elevation that was at least $3.5 \mathrm{ft}$ below the crest of the roadway (fig. 3). Consequently, vehicular traffic over this culvert was not interrupted during the flood.

Flood profiles also can be used to identify possible constrictions in major drainage systems. For example, little or no fall in high- water elevations was noted along Cross Creek for more than 2,000 ft upstream of the CSX Railroad near Hillsboro Street (fig. 5). This indicates that the culvert under this railroad was unable to convey the September 15 flood flows without causing an extensive ponded reach upstream of the culvert. Either the culvert was too small to accommodate the peak flows, or it was clogged with debris during the flood. In fact, a considerable amount of debris was noted at the entrance to the culvert during the high-water mark flagging operations immediately after the flood.

The clogged culvert condition on Cross Creek might be responsible for an apparent inconsistency with the 100-year flood profile along this stream section. The September 15 high-water elevations along Cross Creek are lower than the 


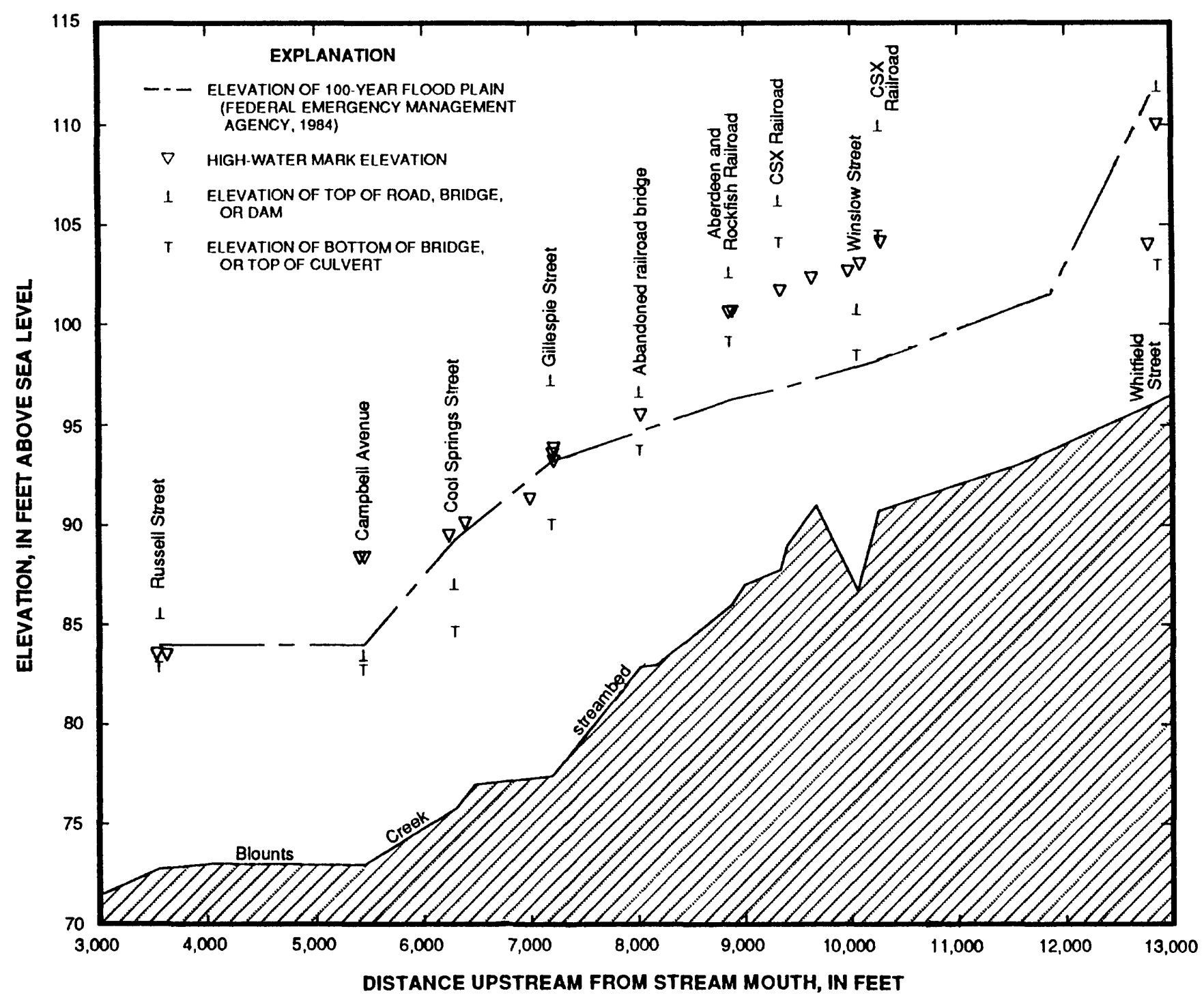

Figure 3. Streambed and 100-year flood profiles along Blounts Creek with bridge and high-water mark elevations for flood of September 15, 1989.

100 -year flood profile through most of the length of the stream, except for the reach upstream of CSX Railroad where they are higher (fig. 5). The apparent inconsistency of the relative positions of the high-water elevations for this reach might be related to assumptions on which the 100-year flood profile computation was based, primarily that the flow of water through culverts would be unobstructed.
The September 15 high-water elevations were greater than the 100-year flood profile along most of Blounts Creek. However, Branson Creek and Hybarts Branch, which received a peak discharge of $6,000 \mathrm{ft}^{3} / \mathrm{s}$ from the failures of Evans Lake and Lockwood Pond dams, had high-water elevations at or slightly less than the 100 -year flood profile (fig. 4). Attenuation of the flood in the channel of Branson Creek and 


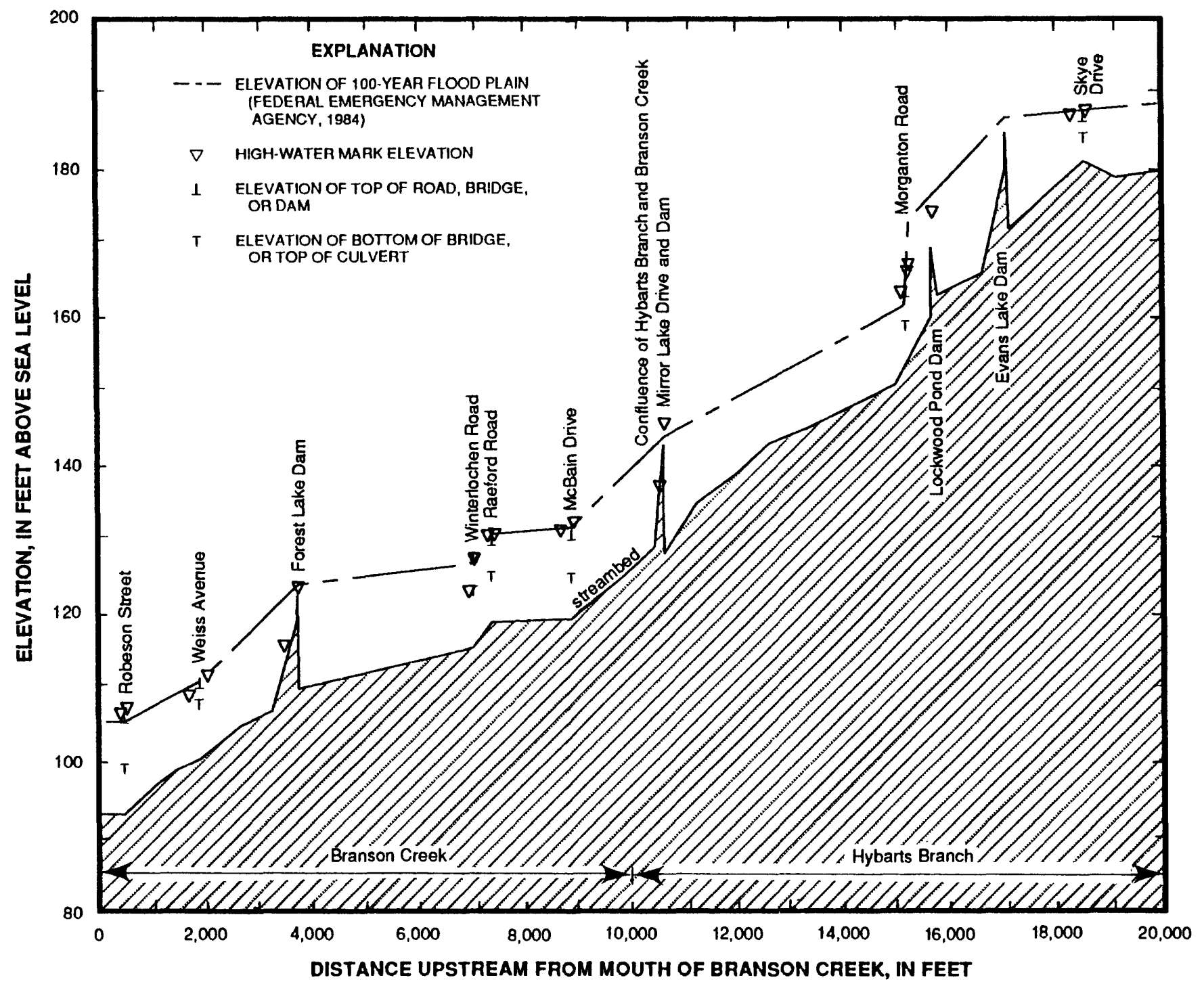

Figure 4. Streambed and 100-year flood profiles along Branson Creek and Hybarts Branch with bridge and high-water mark elevations for flood of September 15, 1989.

by Forest Lake might have reduced the high-water elevations along Branson Creek below predicted 100-year flood levels, but the apparent rapid attenuation of the peak discharge in Hybarts Branch, given the relative shortness of the stream, is unexplained.

\section{Flood-Inundation Maps}

Maps of the areas inundated by the September 15 flood were constructed using high-water elevations and small-ratio scale city topographic maps $(1: 1,200$ or $1: 2,400)$. The locations of the high-water marks were plotted on the maps, and lines were drawn through them, normal to the streams, to intersect map contours corresponding to the elevations of the highwater marks. Flood boundaries were then drawn along the map contours. Interpolations of high-water elevations at other sites were prorated on a stream-depth basis. Major reductions in high-water elevations (if needed through an unsurveyed stream reach) were indicated as having occurred on the downstream face of significant channel constrictions. Field reconnaissance and interviews with local residents were conducted in each neighborhood to verify computed flood boundaries. The small-ratio scale flood maps were then 


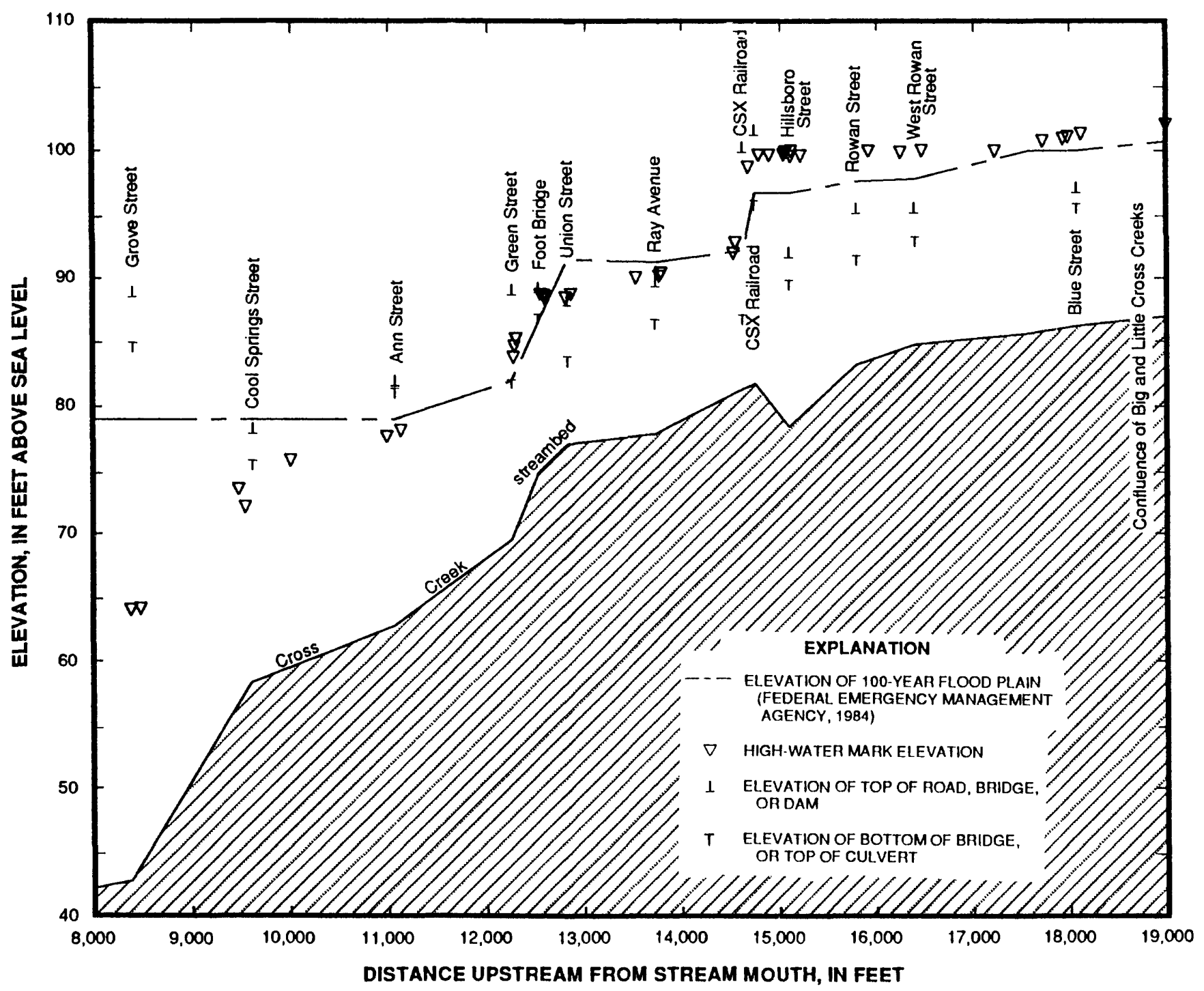

Figure 5. Streambed and 100-year flood profiles along Cross Creek with bridge and high-water mark elevations for flood of September 15, 1989.

compiled onto larger ratio scale $(1: 24,000)$ USGS topographic maps (pl. 1). The small-ratio scale flood-boundary maps are available for inspection in USGS archives or in the City Engineer's office, City of Fayetteville.

A flood-inundation map for the September 15, 1989, storm showed that more than 925 acres of land were inundated (pl. 1), and 338 buildings were flooded to some extent. Relatively little damage was noted along small tributaries; most of the damage occurred along the main stems of larger streams, primarily Hybarts Branch and Branson, Blounts, Little Cross, Big Cross, and Cross Creeks. Many of the damaged buildings were in commercial and residential districts between Murchison Road and Hay Street (pl. 1). Most of the private homes that were damaged were located in residential districts south of Person Street and east of Gillespie Street.

Comparison of the September 15 flooded area with the boundaries shown on Flood-Insurance Rate Maps (Federal Emergency Management Agency, 1984), indicates close agreement (pl. 1); the areas inundated by the September 15 flood are nearly identical to those included in the 100-year flood plain along some reaches of Blounts and Cross Creeks. Some differences were noted, however. The 100 -year floodplain boundaries exceeded the extent of the September 15 


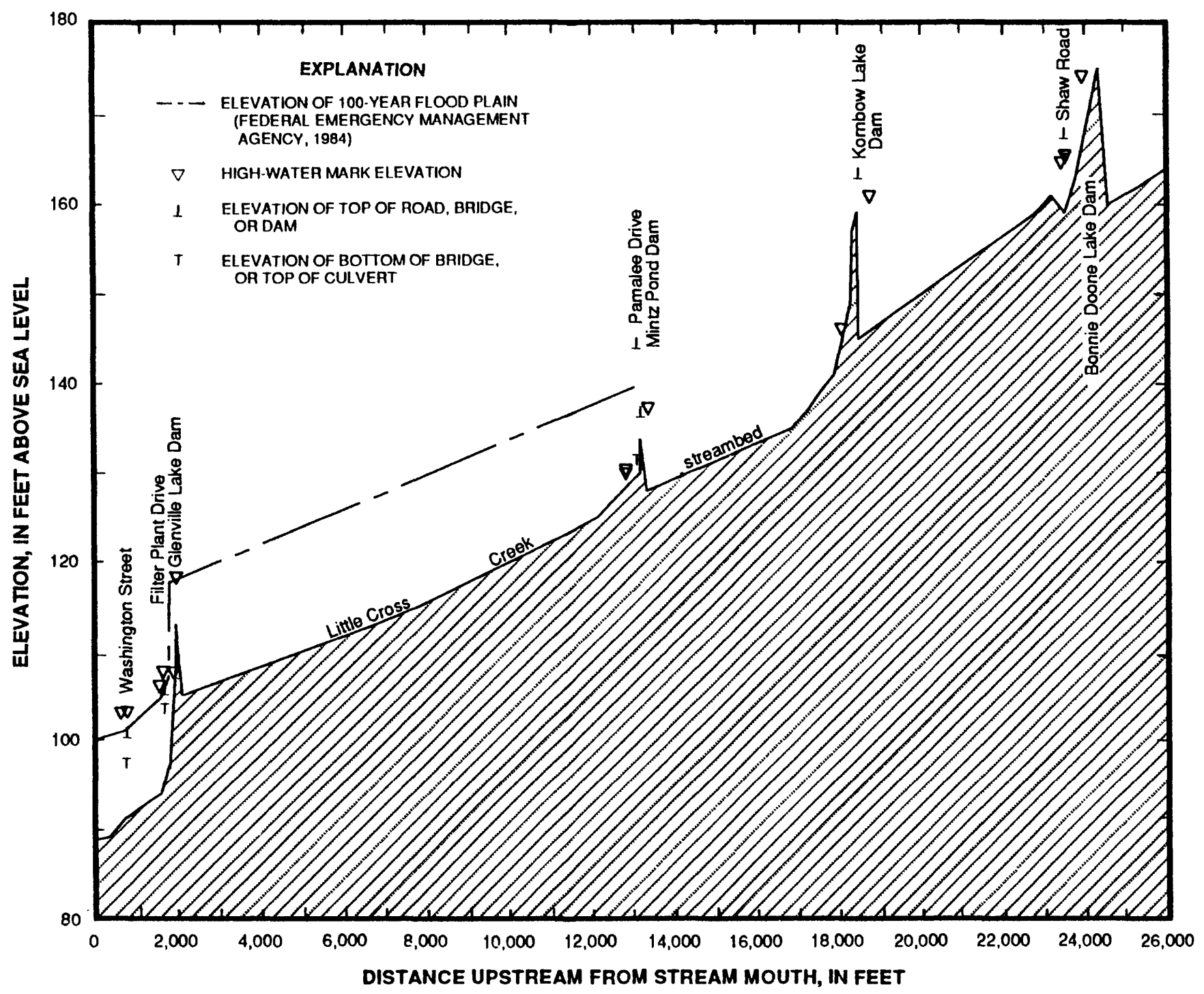

Figure 6. Streambed and 100-year flood profiles along Little Cross Creek with bridge and high-water mark elevations for flood of September 15, 1989.

flood along upstream reaches of Hybarts Branch and Branson and Little Cross Creeks, whereas the areal extent of the September 15 flood exceeded the 100-year flood-plain boundaries along downstream reaches of Blounts Creek. The largest difference is in the area east of Blounts Creek and south of Person Street, where flood water during September 15 covered twice as much area as the 100 -year flood plain.

\section{Rainfall-Intensity and Flood-Peak Frequencies}

A frequency curve relates the magnitude of a variable to the frequency or probability of its occurrence (Riggs, 1968). In hydrologic studies of floods, the probability of occurrence refers to the probability that an event of a specified magnitude will be equaled or exceeded once during a 


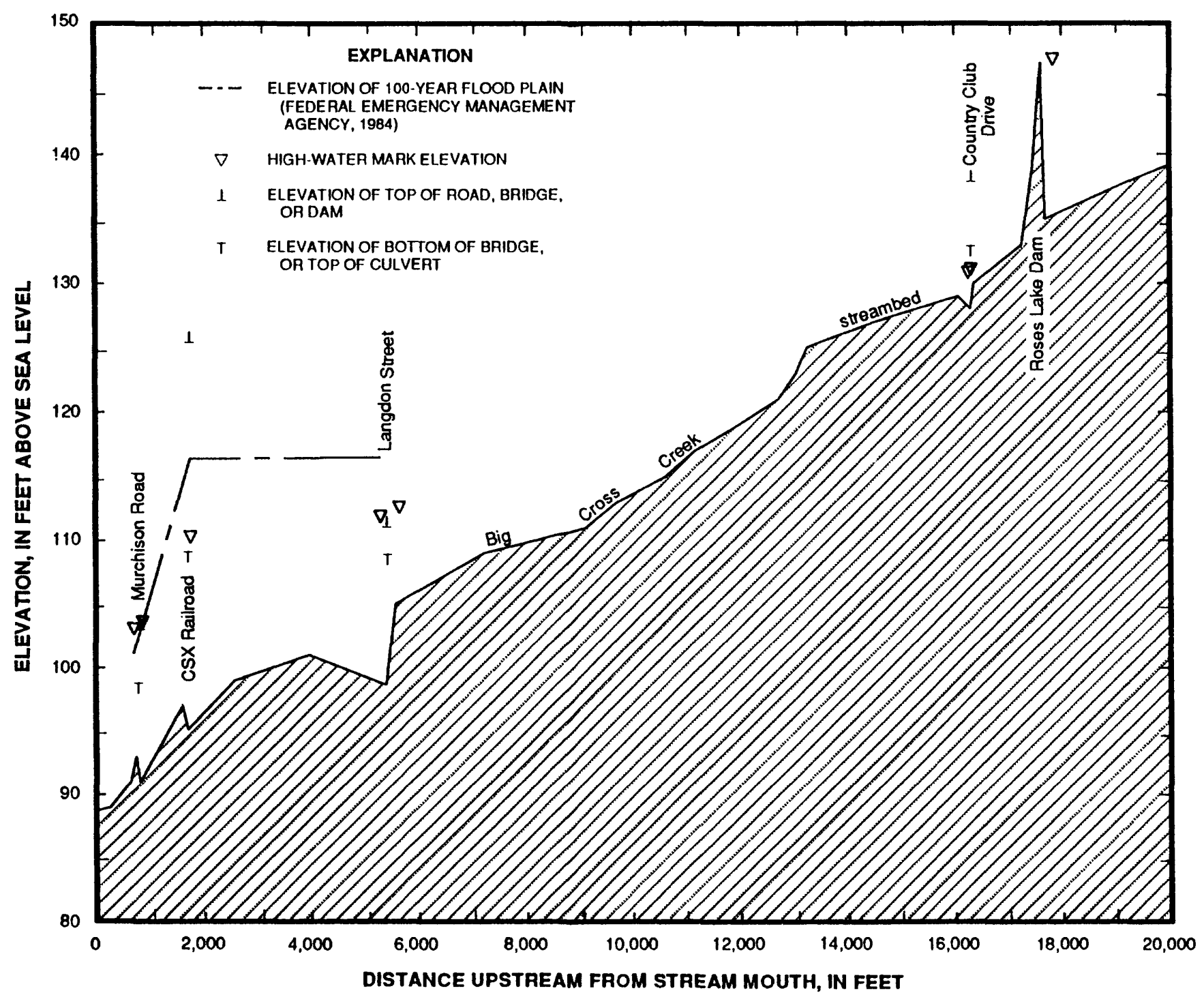

Figure 7. Streambed and 100-year flood profiles along Big Cross Creek with bridge and high-water mark elevations for flood of September 15, 1989.

given period. The reciprocal of the probability of occurrence is the average recurrence interval of an event. In rainfallintensity frequency and flood-frequency analysis, the recurrence interval is usually expressed in years and is the average number of years during which a storm or flood of a given magnitude can be expected to be equaled or exceeded once. Frequency curves are determined from analysis of long-term data, but regionally applicable techniques for estimating rainfall-intensity frequency and flood-frequency curves have been prepared for most areas of the United States and are used where historic data are lacking.

Rainfall data collected during the September 15 storm (table 2) are compared with rainfall-intensity frequency curves constructed from data taken from the National Weather Service (U.S. Department of Commerce, 1961) for storms of the same durations for recurrence intervals of 1 to 100 years (fig. 10). Although rainfall was intense throughout the storm, rainfall amounts for durations of less than 2 hours were not exceptionally rare or unusual (fig. 10). In fact, the 


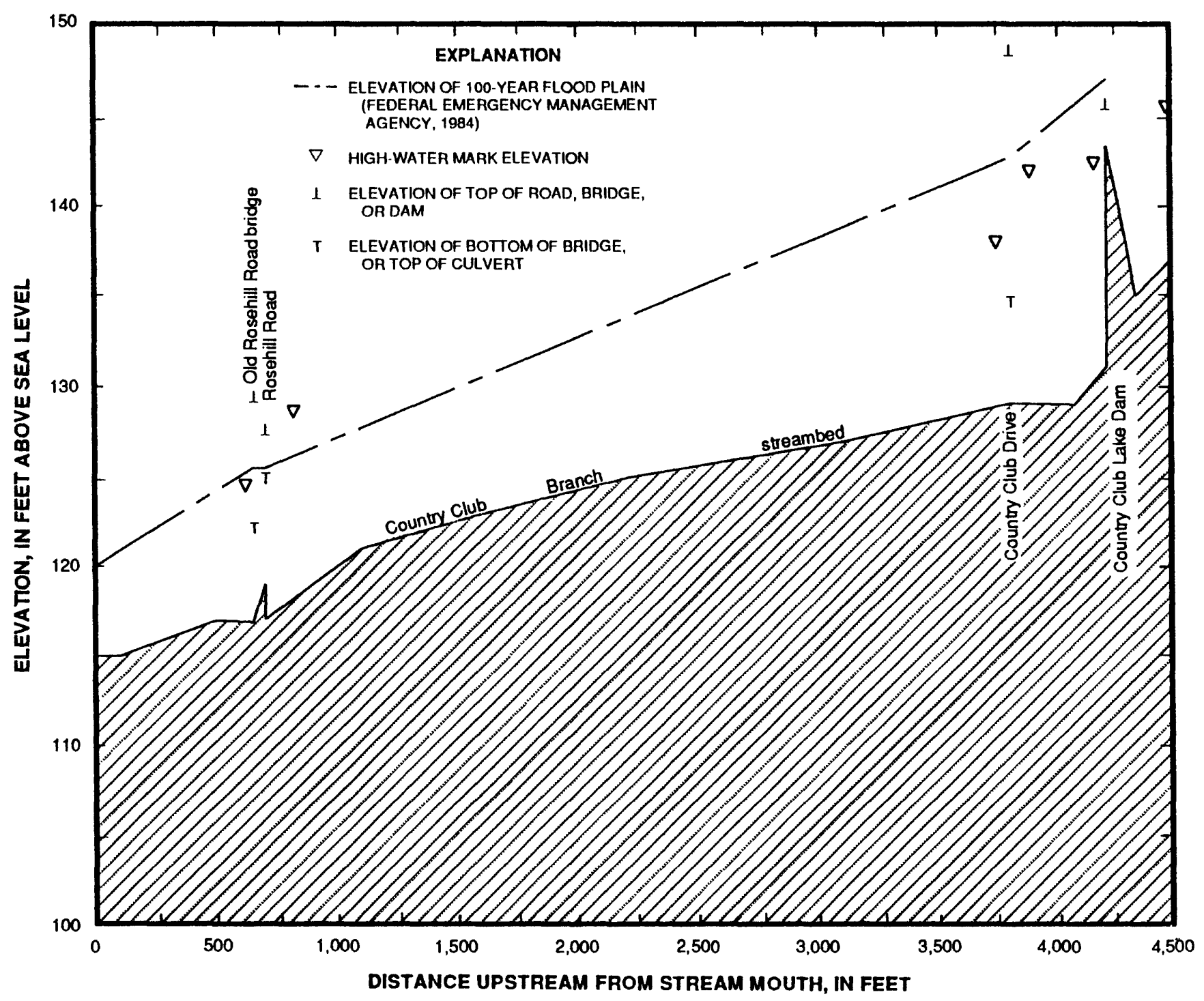

Figure 8. Streambed and 100-year flood profiles along Country Club Branch with bridge and high-water mark elevations for flood of September 15, 1989.

recurrence interval for the greatest 5-minute rainfall recorded (0.40 in.) was less than the annual 5 -minute storm rainfall, and the highest recurrence interval for the 10 -minute rainfall ( 0.75 in.) was less than the 2-year 10 -minute storm rainfall. Of the rainfall amounts for durations of 1 hour or less, only the rainfall for the 1-hour duration recorded at the National Weather Service rain gage exceeded that of a 25 -year storm. When longer rainfall durations are considered, the rainfall amounts measured at the National Weather Service rain gage (site 11) exceed the 2-, 3-, and 6-hour durations expected of
100 -year storms by approximately 31,28 , and 12 percent, respectively (fig. 10). However, the rainfall data collected at the Cape Fear tributary station, site 1, indicate lesser rainfallintensity frequency of 25- to 50-year recurrence intervals for the 2-hour duration.

To estimate the recurrence intervals for the September 15 peak discharges, a flood-frequency distribution was determined for each gage site by applying relations established for estimating peak discharges of urban streams. These relations were developed by Sauer and others (1983) 


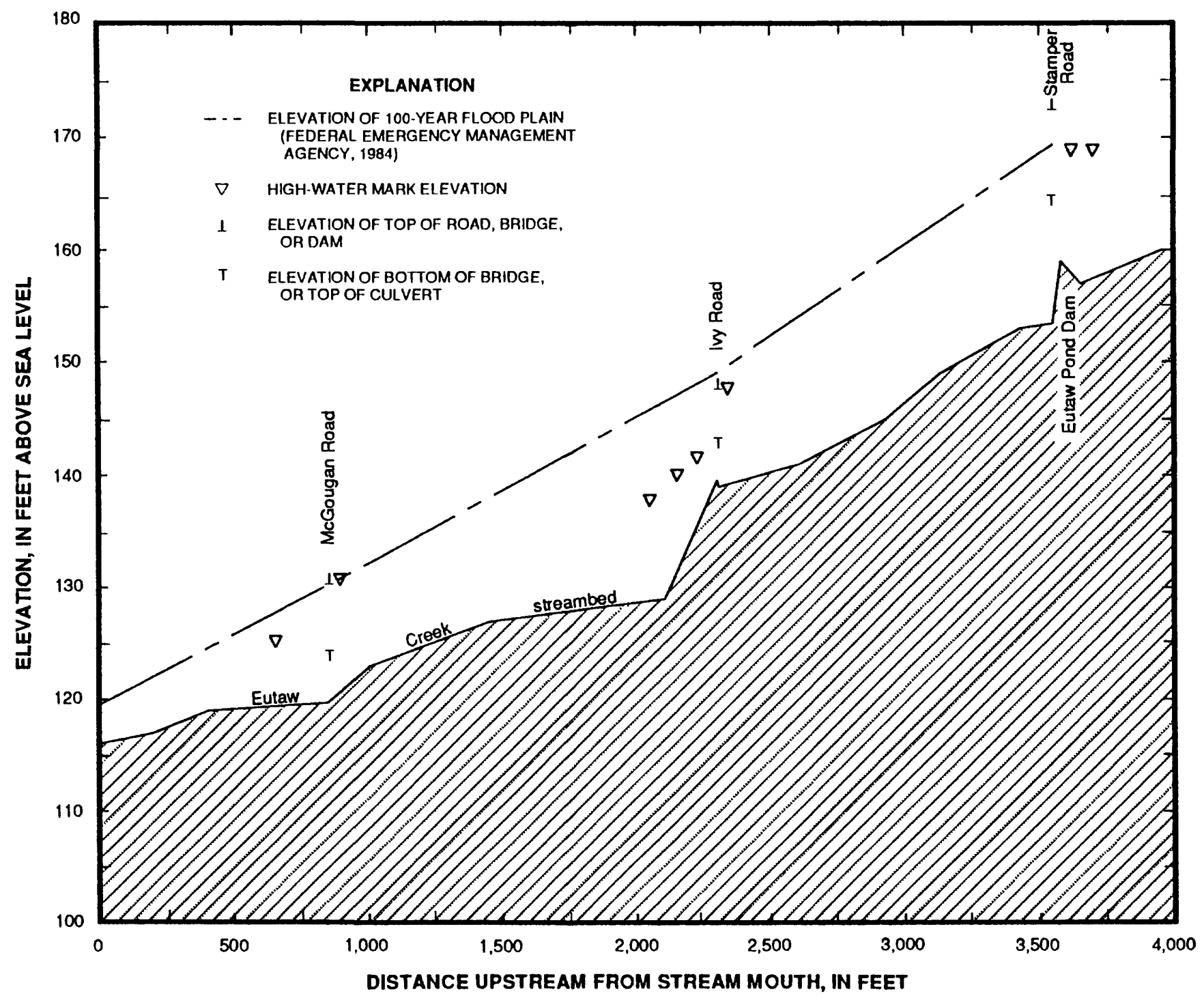

Figure 9. Streambed and 100-year flood profiles along Eutaw Creek with bridge and high-water mark elevations for flood of September 15, 1989.

and are referred to as the nationwide relations. Sauer (1985) showed that these relations are applicable throughout the southeastern United States, and Gunter and others (1987) verified that the relations are applicable, within reasonable limits of accuracy, to the North Carolina Coastal Plain.

Application of the nationwide relations requires an estimate of the peak discharge for the site in rural or undeveloped conditions. For this study, the equivalent rural discharges were computed from relations developed by Gunter and others (1987) for the Sand Hills region of North
Carolina. The nationwide relations are used to adjust this estimate from rural to urban conditions by applying a basindevelopment factor and percentage of impervious area as indexes of urbanization. Variables used in the nationwide relations are contributing drainage area; main channel slope; 2-year, 2-hour rainfall; basin storage; basin-development factor; impervious area; and equivalent rural discharge.

The products of this analysis are flood-frequency curves for each site. Each curve represents an estimate of the magnitude and frequency of floods for the site that might be 


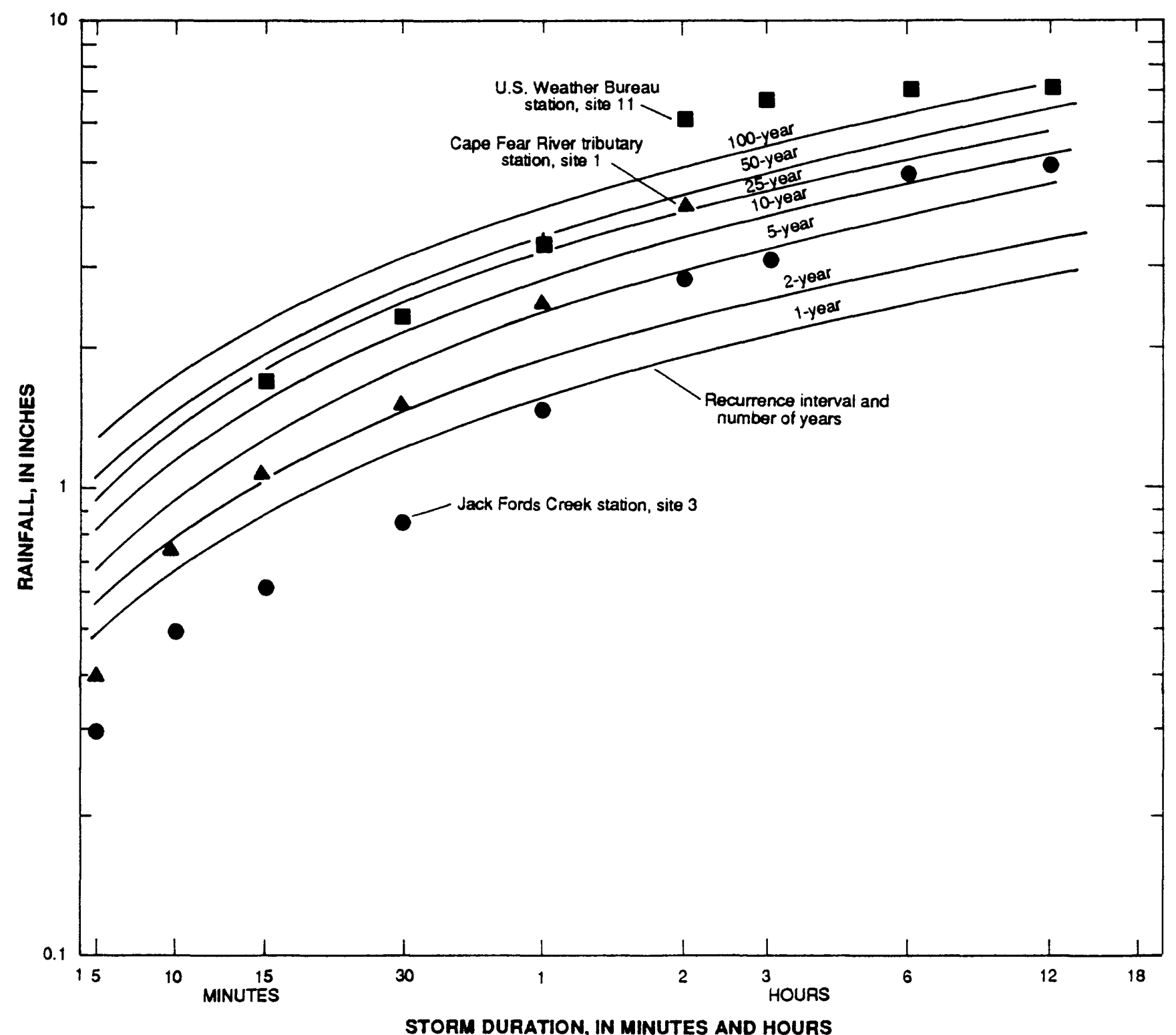

Figure 10. Rainfall-intensity frequency curves for selected recurrence intervals and maximum observed rainfall totals for selected durations for storm of September 15, 1989, at Fayetteville, North Carolina.

expected over a long period under current conditions of urban development. The expected, or normal, range of error for these estimates is indicated by the standard errors of estimate for the nationwide relations. The standard errors of estimate, the observed September 15 peak discharges and unit-peak discharges, and the computed flood-frequency discharges are summarized in table 3.

Preparation of many of the flood-frequency values for the Fayetteville sites required extrapolation of some of the basin characteristics beyond the ranges of those characteristics that were used to develop the nationwide relations. For this reason, the values in table 3 should be interpreted and applied with caution. However, the estimated flood- frequency values do seem to be reasonable and generally agree with estimates developed previously for nearby or downstream sites. For example, the 100 -year flood discharge of $2,090 \mathrm{ft}^{3} / \mathrm{s}$ for Blounts Creek at Gillespie Street (site 10, pl. 1; table 3), which has a drainage area of $10.7 \mathrm{mi}^{2}$, agrees well with the 100 -year flood discharge of $2,050 \mathrm{ft}^{3} / \mathrm{s}$ developed previously by the U.S. Army Corps of Engineers for Blounts Creek at its mouth, which has a drainage area of $11.5 \mathrm{mi}^{2}$ (Federal Emergency Management Agency, 1984).

The September 15 peak discharges at all of the urban sites except Bonnie Doone Lake (site 2) exceed the estimated 50 -year flood discharge, and peak discharges at 6 of the 10 sites exceed the estimated 100-year flood discharge (table 3 ). 
The sites where the 100-year flood discharge was not exceeded are generally in the northern part of the city where, as described earlier, rainfall intensities were probably less. The occurrence there of floods of lesser recurrence intervals is consistent with observed lesser rainfall intensities.

The failures of the dams at Evans Lake, Lockwood Pond, Eutaw Pond, and Country Club Lake complicate floodfrequency analyses of the September 15 flood at downstream sites 8,9 , and $10(\mathrm{pl} .1)$. The nationwide relations are applicable only at basins where little or no significant detention storage is present. The failures of the dams released substantial quantities of water that are not accounted for in the flood-frequency analyses. However, the analyses can be used to assess the frequencies of flood discharges resulting from a storm comparable to the September 15 storm, but caused by normal rainfall runoff rather than dam failure.

\section{SUMMARY}

The flood of September 15, 1989, was the most extensive flood of Fayetteville since 1945. The flood inundated 925 acres of the city along Cross and Blounts Creeks and their tributaries, flooded 338 buildings, caused damages in excess of $\$ 10$ million, and claimed the lives of two small children. The flood was unique in the history of flooding in Fayetteville in that nearly all of the flood water originated from rain falling within the city or surrounding areas, and much of the damage was due to the failures of earthen dams. Previous floods were due to major flooding of the Cape Fear River that inundated low-lying areas in the eastern parts of the city.

A streamflow and rain-gage network consisting of seven stream-gaging stations and seven rainfall recorders was in operation when the storm and flood struck. Data from these sites and a nearby National Weather Service rain gage indicate that the storm and flood were relatively rare events. During a 6-hour period, as much as 7.20 in. of rain was recorded in some areas of Fayetteville.

The effects of the storm and flood were limited to the immediate vicinity of Fayetteville. No rises in stage or discharge occurred at any of the stream gages on the Cape Fear River upstream of Fayetteville, nor were any significant increases recorded at the stream-gaging station on Flat Creek at Inverness, N.C., $15 \mathrm{mi}$ northwest of Fayetteville.

During the flood, storm runoff filled several small ponds and lakes along Blounts, Branson, Big Cross and Little Cross Creeks, and their tributaries as water flowed from upland areas to the Cape Fear River. The effect of this filling was to attenuate the flood by reducing peak discharges and delaying the onrush of flood water. Reservoir-induced attenuation reduced the peak discharge at Bonnie Doone Lake from 225 to $99 \mathrm{ft}^{3} / \mathrm{s}$, but at sites downstream of breached dams, the peak discharges were substantially higher than they would have been had the dams not failed.
Observations of 117 high-water marks and data at 57 bridges, culverts, and dams supplemented the network data base. These data were used to construct flood profiles which showed that 22 roads and 5 dams were overtopped during the September 15 flood. High-water elevations from the flood were lower than the 100-year flood elevations along most of the lengths of Cross Creek and Blounts Creek upstream of Robeson Street. Downstream of Robeson Street, the highwater elevations were mostly higher than the 100 -year flood profile.

Comparison of the September 15 flood boundaries to those shown on Flood-Insurance Rate Maps indicates close agreement. However, the 100-year flood-plain boundaries exceeded the areal extent of the September 15 flood along upstream reaches of Hybarts Branch, Branson Creek, and Little Cross Creek, whereas the extent of the September 15 flood exceeded the 100-year flood-plain boundaries along downstream reaches of Blounts Creek.

Rainfall amounts for durations of less than 2 hours were not rare or unusual. The recurrence interval for the greatest 5 -minute rainfall of $0.40 \mathrm{in}$. was less than that expected of the annual 5-minute storm rainfall. Of the rainfall amounts for durations of 1 hour or less, only the rainfall at the National Weather Service rain gage exceeded that expected for the 1-hour, 25-year storm. However, rainfall amounts at the National Weather Service gage exceeded those expected of the 2-, 3-, and 6-hour, 100-year storms.

Flood-frequency curves were prepared for each network site to provide an estimate of the magnitude and frequency of floods that might be expected over a long period under current urban conditions. Peak discharges from the September 15 flood ranged from 33 to $6,060\left(\mathrm{ft}^{3} / \mathrm{s}\right) / \mathrm{mi}^{2}$ and exceeded the estimated 50-year flood discharge at all sites except at Bonnie Doone Lake (site 2). Peak discharges also exceeded the 100 -year discharge at 6 of 10 sites. Most of the sites which recorded discharges of lesser recurrence intervals were in the northern section of the city where there was less rainfall.

\section{REFERENCES}

Barnes, Marc, 1989, Cold air met warm and skies opened: The Fayetteville Observer-Times, September 18, 1989, Fayetteville, N.C., p. 14a.

Barrett, Mike, 1989, Rain damage to city, $\$ 10$ million: The Fayetteville Observer-Times, September 18, 1989, Fayetteville, N.C., p. 1 a.

Benson, M.A., and Dalrymple, Tate, 1976, General field and office procedures for indirect discharge measurements: U.S. Geological Survey Techniques of Water-Resources Investigations, Bk. 3, Chap. A1, 30 p.

Bodhaine, G.L., 1968, Measurement of peak discharge at culverts by indirect methods: U.S. Geological Survey Techniques of Water-Resources Investigations, Bk. 3, Chap. A3, 60 p. 
Cochran, W.G., 1963, Sampling techniques: New York, John Wiley, p. 71-86.

Dalrymple, Tate, and Benson, M.A., 1976, Measurement of peak discharge by the slope-area method: U.S. Geological Survey Techniques of Water-Resources Investigations, Bk. 3, Chap. A2, 12 p.

Daniels, R.B., Kleiss, H.J., Buol, S.W., Byrd, H.J., and Phillips, J.A., 1984, Soil systems in North Carolina: North Carolina State University, North Carolina Agricultural Research Service, Bulletin 467, 77 p.

Federal Emergency Management Agency, 1984, Flood insurance rate map, City of Fayetteville, North Carolina, Cumberland County: Federal Emergency Management Agency, National Flood Insurance Program, Community-Panel Numbers $3700770001 \mathrm{C}$ through 370077 0018, revised June 1984.

Gunter, H.C., Mason, R.R., Stamey, T.C., 1987, Magnitude and frequency of floods in rural and urban basins of North Carolina: U.S. Geological Survey Water-Resources Investigations Report 87-4096, 52 p.

Hudson, B.D., 1984, Soil survey of Cumberland and Hoke Counties, North Carolina: U.S. Department of Agriculture, Soil Conservation Service, $155 \mathrm{p}$.

Hulsing, Harry, 1968, Measurement of peak discharge at dams by indirect methods: U.S. Geological Survey Techniques of Water-Resources Investigations, Bk. 3, Chap. A5, 29 p.

National Oceanic and Atmospheric Administration, 1989a, Climatological data, North Carolina, September 1989: Asheville, N.C., National Climatic Data Center, v. 94, no. 9, $32 \mathrm{p}$.

----1989b, Hourly precipitation, North Carolina, September 1989: Asheville, N.C., National Climatic Data Center, v. 39, no. 9, $16 \mathrm{p}$.

---1990, Climatological data, annual summary, North Carolina, 1989: Asheville, N.C., National Climatic Data Center, v. 94, no. $13,38 \mathrm{p}$.
Ragland, B.C., Barker, R.B., Eddins, W.H., and Rinehardt, J.F., 1990, Water resources data, North Carolina, water year 1989: U.S. Geological Survey Water-Data Report NC-89-1, 389 p.

Reese, Pat, 1989, Incessant storm drenches city; two children drown in creek: The Fayetteville Observer-Times, September 17, 1989, Fayetteville, N.C., p. 1.

Riggs, H.C., 1968, Frequency curves: U.S. Geological Survey Techniques of Water-Resources Investigations, Bk. 4, Chap. A2, $15 \mathrm{p}$.

Sauer, V.B., 1985, New studies of urban flood frequency in the southeastern United States, in International symposium on urban hydrology: Lexington, Ky., 1985, 4 p.

Sauer, V.B., Thomas, W.O., Jr., Stricker, V.A., and Wilson, K.V., 1983, Flood characteristics of urban watersheds in the United States-Techniques for estimating magnitude and frequency of urban floods: U.S. Geological Survey Water-Supply Paper 2207, 103 p.

U.S. Army Corps of Engineers, 1970, Flood plain information, Cape Fear River and Cross Creek watershed, Fayetteville, North Carolina: U.S. Army Corps of Engineers, Wilmington, N.C., District, 81 p.

U.S. Department of Agriculture, 1972, Hydrology: Soil Conservation Service National Engineering Handbook, Sect. 4, Chap. 7, 28 p.

U.S. Department of Commerce, 1961, Rainfall frequency atlas of the United States for durations from $\mathbf{3 0}$ minutes to $\mathbf{2 4}$ hours and return periods from 1 to 100 years: Washington, D.C., U.S. Government Printing Office, Weather Bureau Technical Paper No. 40, 115 p.

----1991, 1990 decennial census, in Post census local review: U.S. Census Bureau, Washington, D.C.

Viessman, Warren, Jr., Knapp, J.K., Lewis, G.L., and Harbaugh, T.E., 1977, Introduction to hydrology, 2nd ed.: New York, Harper and Row, 704 p 
Appendix 


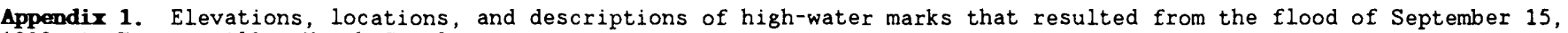
1989, in Fayetteville, North Carolina

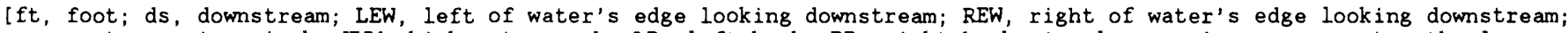
us., upstream; in., inch; HWM, high-water mark; LB, left bank; RB, right bank; \pm , plus or minus; $>$, greater than]

\begin{tabular}{|c|c|c|c|c|}
\hline $\begin{array}{c}\text { High- } \\
\text { water } \\
\text { mark } \\
\text { identi- } \\
\text { fication } \\
\text { number } \\
\text { (pl. 1) }\end{array}$ & Accuracy ${ }^{1}$ & $\begin{array}{l}\text { High- } \\
\text { water } \\
\text { mark } \\
\text { elevation } \\
\text { ( } f t \\
\text { above } \\
\text { sea level) }\end{array}$ & $\begin{array}{l}\text { Distance } \\
\text { upstream } \\
\text { from } \\
\text { mouth } \\
\text { (ft) }\end{array}$ & Description of high-water mark ${ }^{2}$ \\
\hline \multicolumn{5}{|c|}{ Blounts Creek (BC) } \\
\hline $\begin{array}{l}B C-1 \\
B C-2 \\
B C-3 \\
B C-4 \\
B C-5\end{array}$ & $\begin{array}{l}\text { Excellent } \\
\text { Excellent } \\
\text { Poor } \\
\text { Excellent } \\
\text { Excellent }\end{array}$ & $\begin{array}{l}83.52 \\
83.48 \\
88.34 \\
88.37 \\
89.49\end{array}$ & $\begin{array}{l}3,480 \\
3,575 \\
5,360 \\
5,405 \\
6,150\end{array}$ & $\begin{array}{l}\text { Seedline on large pine tree } 20 \mathrm{ft} \text { ds bridge, } 25 \mathrm{ft} \text { LEW. } \\
\text { Drift line } 75 \mathrm{ft} \text { us. bridge, } 20 \mathrm{ft} \text { REW. } \\
\text { Debris on chain link fence } 40 \mathrm{ft} \mathrm{ds}, 250 \mathrm{ft} \mathrm{LEW} \text {. } \\
\text { Seedline on church } 5 \mathrm{ft} \text { us. bridge, } 500 \mathrm{ft} \text { REW. } \\
\text { Seedline on church } 100 \mathrm{ft} \text { ds bridge, } 110 \mathrm{ft} \text { REW. }\end{array}$ \\
\hline $\begin{array}{l}B C-6 \\
B C-7 \\
B C-8 \\
B C-9 \\
B C-10\end{array}$ & $\begin{array}{l}\text { Excellent } \\
\text { Excellent } \\
\text { Good } \\
\text { Fair } \\
\text { Fair }\end{array}$ & $\begin{array}{l}90.10 \\
91.43 \\
93.51 \\
93.85 \\
93.20\end{array}$ & $\begin{array}{l}6,340 \\
6,900 \\
7,285 \\
7,345 \\
7,345\end{array}$ & $\begin{array}{l}\text { Seedline on } 10 \text { in. oak tree } 90 \mathrm{ft} \text { us. bridge, } 15 \mathrm{ft} \text { LEW. } \\
\text { Seedline on building } 250 \mathrm{ft} \mathrm{ds} \text { culvert, } 75 \mathrm{ft} \mathrm{REW} \text {. } \\
\text { Drift line } 135 \mathrm{ft} \text { us. culvert, } 15 \mathrm{ft} \text { REW. } \\
\text { Seedline on } 9 \text { in. tree } 195 \mathrm{ft} \text { us. culvert, } 10 \mathrm{ft} \mathrm{REW} . \\
\text { Seedline on } 9 \mathrm{in.} \text { tree } 195 \mathrm{ft} \text { us. culvert, } 10 \mathrm{ft} \mathrm{REW} \text {. }\end{array}$ \\
\hline $\begin{array}{l}B C-11 \\
B C-12 \\
B C-13 \\
B C-14 \\
B C-15\end{array}$ & $\begin{array}{l}\text { Poor } \\
\text { Excellent } \\
\text { Fair } \\
\text { Poor } \\
\text { Fair }\end{array}$ & $\begin{array}{r}95.51 \\
100.60 \\
100.64 \\
101.70 \\
102.30\end{array}$ & $\begin{array}{l}7,975 \\
8,805 \\
8,840 \\
9,285 \\
9,485\end{array}$ & $\begin{array}{l}\text { Good debris line on railroad but may have settled. } \\
\text { Seedline in garage } 20 \mathrm{ft} \text { ds bridge, } 150 \mathrm{ft} \text { REW. } \\
\text { Mudline under bridge, } 15 \mathrm{ft} \text { REW. } \\
\text { Mudline under bridge, } 25 \mathrm{ft} \text { REW. } \\
\text { Seedline on building, } 200 \mathrm{ft} \text { us. bridge, } 950 \mathrm{ft} \text { LEW. }\end{array}$ \\
\hline $\begin{array}{l}B C-16 \\
B C-17 \\
B C-18 \\
B C-19 \\
B C-20\end{array}$ & $\begin{array}{l}\text { Excellent } \\
\text { Fair } \\
\text { Good } \\
\text { Excellent } \\
\text { Good }\end{array}$ & $\begin{array}{l}102.66 \\
103.05 \\
104.13 \\
103.97 \\
111.54\end{array}$ & $\begin{array}{l}9,925 \\
10,035 \\
10,230 \\
12,730 \\
12,815\end{array}$ & $\begin{array}{l}\text { Seedline on } 24 \text { in. oak tree } 85 \mathrm{ft} \text { ds bridge, } 100 \mathrm{ft} \text { LEW. } \\
\text { Seedline on } 8 \text { in. pine tree } 25 \mathrm{ft} \text { us. bridge, } 150 \mathrm{ft} \text { LEW. } \\
\text { Seedline on telephone pole } 20 \mathrm{ft} \text { us. bridge, } 25 \mathrm{ft} \text { LEW. } \\
\text { Seedline on house } 80 \mathrm{ft} \text { ds of culvert, } 85 \mathrm{ft} \text { REW. } \\
\text { Debris line } 5 \mathrm{ft} \text { us. of culvert, } 35 \mathrm{ft} \text { LEW. }\end{array}$ \\
\hline \multicolumn{5}{|c|}{ Branson Creek (BRC) } \\
\hline $\begin{array}{l}\text { BRC-1 } \\
\text { BRC-2 } \\
\text { BRC-3 } \\
\text { BRC-4 } \\
\text { BRC-5 }\end{array}$ & $\begin{array}{l}\text { Good } \\
\text { Fair } \\
\text { Excellent } \\
\text { Good } \\
\text { Good }\end{array}$ & $\begin{array}{l}106.53 \\
107.26 \\
108.96 \\
111.70 \\
115.74\end{array}$ & $\begin{array}{r}405 \\
525 \\
1,675 \\
2,025 \\
3,475\end{array}$ & $\begin{array}{l}\text { Seedline on tree } 70 \mathrm{ft} \text { ds culvert, } 10 \mathrm{ft} \text { LEW. } \\
\text { Seedline on } 15 \mathrm{in.} \text { pine tree } 50 \mathrm{ft} \text { us. culvert, } 70 \mathrm{ft} \text { REW. } \\
\text { Seedline on house } 200 \mathrm{ft} \mathrm{ds} \text { bridge, } 200 \mathrm{ft} \text { LEW. } \\
\text { Seedline on house } 150 \mathrm{ft} \text { us. bridge, } 200 \mathrm{ft} \text { LEW. } \\
\text { Seedline on } 30 \mathrm{in} \text { pine tree } 250 \mathrm{ft} \mathrm{ds} \mathrm{dam}, 50 \mathrm{ft} \text { REW. }\end{array}$ \\
\hline $\begin{array}{l}\text { BRC- } 6 \\
\text { BRC-7 } \\
\text { BRC-8 } \\
\text { BRC-9 } \\
\text { BRC- } 10\end{array}$ & $\begin{array}{l}\text { Good } \\
\text { Good } \\
\text { Good } \\
\text { Good } \\
\text { Good }\end{array}$ & $\begin{array}{l}123.51 \\
123.01 \\
127.37 \\
130.51 \\
130.66\end{array}$ & $\begin{array}{l}3,765 \\
6,950 \\
7,050 \\
7,300 \\
7,430\end{array}$ & $\begin{array}{l}\text { Seedline on } 12 \mathrm{in} \text {. pine tree } 40 \mathrm{ft} \text { us. dam, } 40 \mathrm{ft} \text { REW. } \\
\text { Seedline on door of house } 75 \mathrm{ft} \text { ds culvert, } 100 \mathrm{ft} \text { LEW. } \\
\text { Seedline on fence } 25 \mathrm{ft} \text { us. culvert, } 25 \mathrm{ft} \text { REW. } \\
\text { Seedline on switch box } 75 \mathrm{ft} \text { ds culvert, } 300 \mathrm{ft} \text { LEW. } \\
\text { Seedline on fence } 55 \mathrm{ft} \text { us. culvert, } 400 \mathrm{ft} \text { LEW. }\end{array}$ \\
\hline $\begin{array}{l}\text { BRC-11 } \\
\text { BRC-12 } \\
\text { BRC-13 } \\
\text { BRC- } 14\end{array}$ & $\begin{array}{l}\text { Excellent } \\
\text { Good } \\
\text { Fair } \\
\text { Excellent }\end{array}$ & $\begin{array}{l}131.20 \\
132.35 \\
170.12 \\
172.25\end{array}$ & $\begin{array}{r}8,675 \\
8,925 \\
16,800 \\
16,920\end{array}$ & $\begin{array}{l}\text { Seedline on tool shed } 200 \mathrm{ft} \text { ds culvert, } 175 \mathrm{ft} \text { LEW. } \\
\text { Seedline on pine tree } 50 \mathrm{ft} \text { us. culvert, } 65 \mathrm{ft} \text { LEW. } \\
\text { Seedline on } 4 \text { in. pine tree } 75 \mathrm{ft} \text { ds culvert, } 5 \mathrm{ft} \text { LEW. } \\
\text { Seedline on } 6 \text { in. hickory tree } 45 \mathrm{ft} \text { us. culvert, } 45 \mathrm{ft} \text { LEW. }\end{array}$ \\
\hline \multicolumn{5}{|c|}{ Hybarts Branch (HC) } \\
\hline $\begin{array}{l}\mathrm{HC}-1 \\
\mathrm{HC}-2 \\
\mathrm{HC}-3 \\
\mathrm{HC}-4 \\
\mathrm{HC}-5\end{array}$ & $\begin{array}{l}\text { Poor } \\
\text { Excellent } \\
\text { Fair } \\
\text { Fair } \\
\text { Fair }\end{array}$ & $\begin{array}{l}137.19 \\
145.71 \\
163.30 \\
166.06 \\
167.10\end{array}$ & $\begin{array}{r}360 \\
420 \\
4,890 \\
5,010 \\
5,535\end{array}$ & $\begin{array}{l}\text { Seedline on } 14 \mathrm{in.} \mathrm{tree} 40 \mathrm{ft} \text { ds culvert, } 50 \mathrm{ft} \text { LEW. } \\
\text { Seedline on } 8 \text { in. tree } 20 \mathrm{ft} \text { us. culvert, } 50 \mathrm{ft} \text { LEW. } \\
\text { Seedline on } 10 \mathrm{in} \text { pine tree } 60 \mathrm{ft} \mathrm{ds} \text { culvert, } 25 \mathrm{ft} \text { LEW. } \\
\text { Seedline on tree } 60 \mathrm{ft} \text { us. culvert, } 5 \mathrm{ft} \text { LEW. } \\
\text { Seedline on oak tree } 85 \mathrm{ft} \text { us. bridge, } 125 \mathrm{ft} \text { REW. }\end{array}$ \\
\hline $\begin{array}{l}\mathrm{HC}-6 \\
\mathrm{HC}-7 \\
\mathrm{HC}-8\end{array}$ & $\begin{array}{l}\text { Excellent } \\
\text { Excellent } \\
\text { Good }\end{array}$ & $\begin{array}{l}174.20 \\
187.25 \\
187.83\end{array}$ & $\begin{array}{l}5,480 \\
8,070 \\
8,360\end{array}$ & $\begin{array}{l}\text { Seedline on } 3 \mathrm{in} \text {. tree } 30 \mathrm{ft} \text { us. dam, } 10 \mathrm{ft} \text { REW. } \\
\text { Seedline on } 16 \mathrm{in} \text {. tree } 250 \mathrm{ft} \text { ds bridge, } 15 \mathrm{ft} \text { REW. } \\
\text { Seedline on } 8 \text { in. pine tree } 40 \mathrm{us} \text { bridge, } 2 \mathrm{ft} \text { LEW. }\end{array}$ \\
\hline \multicolumn{5}{|c|}{ Cross Creek (CC) } \\
\hline $\begin{array}{l}\text { CC-1 } \\
\text { CC-2 } \\
\text { CC-3 } \\
\text { CC-4 } \\
\text { CC }-5\end{array}$ & $\begin{array}{l}\text { Excellent } \\
\text { Good } \\
\text { Excellent } \\
\text { Excellent } \\
\text { Excellent }\end{array}$ & $\begin{array}{l}63.94 \\
64.02 \\
73.71 \\
72.10 \\
75.78\end{array}$ & $\begin{array}{r}8,375 \\
8,475 \\
9,485 \\
9,550 \\
10,010\end{array}$ & $\begin{array}{l}\text { Seedline on foundation beneath bridge, } 35 \mathrm{ft} \text { LEW. } \\
\text { Seedline on } 10 \mathrm{in} \text {. pine tree } 100 \mathrm{ft} \text { us. bridge, } 75 \mathrm{ft} \text { REW. } \\
\text { Seedline on } 39 \text { in. oak tree, } 125 \mathrm{ft} \mathrm{ds} \text { bridge, } 40 \mathrm{ft} \mathrm{LEW} \text {. } \\
\text { Seedline on millhouse } 60 \mathrm{ft} \mathrm{ds} \text { bridge, } 50 \mathrm{ft} \text { REW. } \\
\text { Seedline on } 36 \mathrm{in} \text {. oak tree } 400 \mathrm{ft} \text { us. bridge, } 60 \mathrm{ft} \text { REW. }\end{array}$ \\
\hline $\begin{array}{l}\text { CC }-6 \\
\text { CC }-7 \\
\text { CC }-8 \\
\text { CC }-9 \\
\text { CC }-10\end{array}$ & $\begin{array}{l}\text { Excellent } \\
\text { Excellent } \\
\text { Fair } \\
\text { Fair } \\
\text { Fair }\end{array}$ & $\begin{array}{l}77.68 \\
78.12 \\
83.80 \\
84.66 \\
85.25\end{array}$ & $\begin{array}{l}10,990 \\
11,130 \\
12,280 \\
12,290 \\
12,305\end{array}$ & $\begin{array}{l}\text { Seedline on } 10 \mathrm{in.} \mathrm{oak} \mathrm{tree} 70 \mathrm{ft} \text { ds bridge, } 25 \mathrm{ft} \text { LEW. } \\
\text { Seedline on } 12 \mathrm{in} \text {. oak tree } 70 \mathrm{ft} \text { us. bridge, } 40 \mathrm{ft} \text { REW. } \\
\text { Mudline on concrete lining } 20 \mathrm{ft} \text { us. dam, 10 ft LEW. } \\
\text { Washline on concrete lining } 30 \mathrm{ft} \text { us. dam, } 10 \mathrm{ft} \text { REW. } \\
\text { Seedline on } 18 \mathrm{in.} \mathrm{oak} \mathrm{tree} 45 \mathrm{ft} \text { us. dam, } 20 \mathrm{ft} \mathrm{LEW} \text {. }\end{array}$ \\
\hline $\begin{array}{l}\mathrm{CC}-11 \\
\mathrm{CC}-12 \\
\mathrm{CC}-13 \\
\mathrm{CC}-14 \\
\mathrm{CC}-15\end{array}$ & $\begin{array}{l}\text { Fair } \\
\text { Excellent } \\
\text { Fair } \\
\text { Fair } \\
\text { Excellent }\end{array}$ & $\begin{array}{l}85.25 \\
88.72 \\
88.40 \\
88.56 \\
88.68\end{array}$ & $\begin{array}{l}12,310 \\
12,575 \\
12,585 \\
12,655 \\
12,665\end{array}$ & $\begin{array}{l}\text { Seedline on } 20 \mathrm{in} \text { oak tree } 50 \mathrm{ft} \text { us dam, } 15 \mathrm{ft} \text { LEW. } \\
\text { Seedline on tunnel wall } 40 \mathrm{ft} \text { us. walkway, } 50 \mathrm{ft} \text { REW. } \\
\text { Seedline on } 12 \mathrm{in.} \text { oak tree } 50 \mathrm{ft} \text { us. walkway, } 30 \mathrm{ft} \text { LEW. } \\
\text { Seedline on } 6 \text { in. oak tree } 120 \mathrm{us} \text {. walkway, } 35 \mathrm{ft} \mathrm{LEW} \text {. } \\
\text { Seedline on tunnel wall } 130 \mathrm{ft} \text { us. walkway, } 50 \mathrm{ft} \text { REW. }\end{array}$ \\
\hline
\end{tabular}

Footnotes are at end of table. 


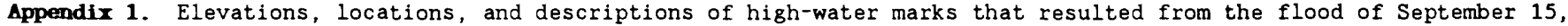
1989, in Fayetteville, North Carolina--Continued

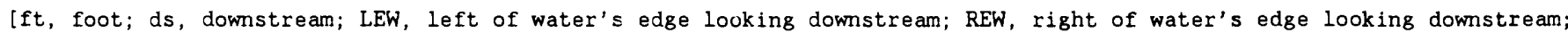
us., upstream; in., inch; HWM, high-water mark; LB, left bank; RB, right bank; \pm , plus or minus; >, greater than]

\begin{tabular}{|c|c|c|c|c|}
\hline $\begin{array}{l}\text { High- } \\
\text { water } \\
\text { mark } \\
\text { identi- } \\
\text { fication } \\
\text { number } \\
\text { (pl. 1) }\end{array}$ & Accuracy ${ }^{1}$ & $\begin{array}{l}\text { High- } \\
\text { water } \\
\text { mark } \\
\text { elevation } \\
\text { (ft } \\
\text { above } \\
\text { sea level) }\end{array}$ & $\begin{array}{l}\text { Distance } \\
\text { upstream } \\
\text { from } \\
\text { mouth } \\
\text { (ft) }\end{array}$ & Description of high-water mark ${ }^{2}$ \\
\hline
\end{tabular}

\begin{tabular}{|c|c|c|c|c|}
\hline $\begin{array}{l}C C-16 \\
C C-17 \\
C C-18 \\
C C-19 \\
C C-20\end{array}$ & $\begin{array}{l}\text { Good } \\
\text { Good } \\
\text { Excellent } \\
\text { Excellent } \\
\text { Excellent }\end{array}$ & $\begin{array}{l}88.46 \\
88.78 \\
90.04 \\
90.19 \\
90.40\end{array}$ & $\begin{array}{l}12,815 \\
12,890 \\
13,535 \\
13,775 \\
13,795\end{array}$ & $\begin{array}{l}\text { Seedline on power pole } 20 \mathrm{ft} \text { ds bridge, } 100 \mathrm{ft} \text { LEW. } \\
\text { Seedline on } 36 \text { in. oak tree } 55 \mathrm{ft} \text { us. bridge, } 350 \mathrm{ft} \text { LEW. } \\
\text { Seedline on } 6 \text { in. oak tree } 200 \mathrm{ft} \text { ds bridge, } 10 \mathrm{ft} \text { REW. } \\
\text { Seedline on telephone pole } 40 \mathrm{ft} \text { us. bridge, } 125 \mathrm{ft} \text { REW. } \\
\text { Seedline on building } 60 \mathrm{ft} \text { us. bridge, } 100 \mathrm{ft} \text { LEW. }\end{array}$ \\
\hline $\begin{array}{l}C C-21 \\
C C-22 \\
C C-23 \\
C C-24 \\
C C-25\end{array}$ & $\begin{array}{l}\text { Fair } \\
\text { Fair } \\
\text { Excellent } \\
\text { Good } \\
\text { Good }\end{array}$ & $\begin{array}{l}91.98 \\
92.80 \\
98.69 \\
99.65 \\
99.64\end{array}$ & $\begin{array}{l}14,335 \\
14,435 \\
14,690 \\
14,800 \\
14,880\end{array}$ & $\begin{array}{l}\text { Seedline on } 24 \mathrm{in.} \text { pine tree } 300 \mathrm{ft} \text { ds culvert, } 150 \mathrm{ft} \text { REW. } \\
\text { Seedline on } 30 \text { in. pine tree } 200 \mathrm{ft} \text { ds culvert, } 150 \mathrm{ft} \text { REW. } \\
\text { Seedline on power pole } 70 \mathrm{ft} \text { ds bridge, } 500 \mathrm{ft} \text { REW. } \\
\text { Seedline on } 6 \text { in. pear tree } 40 \mathrm{ft} \text { us. bridge, } 350 \mathrm{ft} \text { REW. } \\
\text { Seedline on } 8 \text { in. sycamore tree, } 120 \mathrm{ft} \text { us. bridge, } 600 \mathrm{ft} \text { REW. }\end{array}$ \\
\hline $\begin{array}{l}C C-26 \\
C C-27 \\
C C-28 \\
C C-29 \\
C C-30\end{array}$ & $\begin{array}{l}\text { Excellent } \\
\text { Excellent } \\
\text { Excellent } \\
\text { Fair } \\
\text { Excellent }\end{array}$ & $\begin{array}{l}99.67 \\
99.90 \\
99.98 \\
99.55 \\
99.60\end{array}$ & $\begin{array}{l}15,060 \\
15,080 \\
15,135 \\
15,180 \\
15,280\end{array}$ & $\begin{array}{l}\text { Seedline on power pole } 300 \mathrm{ft} \text { us bridge, } 800 \mathrm{ft} \text { REW. } \\
\text { Mudline on traffic sign } 30 \mathrm{ft} \text { ds culvert, } 100 \mathrm{ft} \text { LEW. } \\
\text { Seedline on } 24 \text { in. cedar tree } 25 \mathrm{ft} \text { us. culvert, } 500 \mathrm{ft} \text { LEW. } \\
\text { Seedline on billboard } 70 \mathrm{ft} \text { us. culvert, } 15 \mathrm{ft} \text { REW. } \\
\text { Seedline on telephone pole } 170 \mathrm{ft} \text { us. culvert, } 20 \mathrm{ft} \text { LEW. }\end{array}$ \\
\hline $\begin{array}{l}C C-31 \\
C C-32 \\
C C-33 \\
C C-34 \\
C C-35\end{array}$ & $\begin{array}{l}\text { Poor } \\
\text { Fair } \\
\text { Good } \\
\text { Excellent } \\
\text { Good }\end{array}$ & $\begin{array}{r}99.95 \\
99.84 \\
99.98 \\
99.96 \\
100.74\end{array}$ & $\begin{array}{l}16,060 \\
16,260 \\
16,510 \\
17,335 \\
17,725\end{array}$ & $\begin{array}{l}\text { HWM by owner of garage } 250 \mathrm{ft} \text { us. culvert, } 50 \mathrm{ft} \text { REW. } \\
\text { Seedline on pear tree } 150 \mathrm{ft} \mathrm{ds} \text { culvert, } 50 \mathrm{ft} \mathrm{LEW} \text {. } \\
\text { Mudline on building } 100 \mathrm{ft} \text { us. culvert, } 150 \mathrm{ft} \text { LEW. } \\
\text { Mudline on funeral home } 250 \mathrm{ft} \text { ds culvert, } 80 \mathrm{ft} \mathrm{LEW} \text {. } \\
\text { Mudline on window } 140 \mathrm{ft} \text { us. culvert, } 20 \mathrm{ft} \mathrm{LEW} \text {. }\end{array}$ \\
\hline $\begin{array}{l}C C-36 \\
C C-37 \\
C C-38\end{array}$ & $\begin{array}{l}\text { Good } \\
\text { Good } \\
\text { Excellent }\end{array}$ & $\begin{array}{l}100.92 \\
101.05 \\
101.30\end{array}$ & $\begin{array}{l}17,985 \\
17,985 \\
18,125\end{array}$ & $\begin{array}{l}\text { Seedline on } 24 \mathrm{in.} \mathrm{oak} \text { tree } 100 \mathrm{ft} \text { ds bridge, } 90 \mathrm{ft} \text { LEW. } \\
\text { Seedline on } 9 \mathrm{in.} \text { oak tree } 100 \mathrm{ft} \mathrm{ds} \text { bridge, } 40 \mathrm{ft} \text { REW. } \\
\text { Seedline on } 4 \mathrm{in} \text {. cherry tree } 40 \mathrm{ft} \text { us. bridge, } 125 \mathrm{ft} \text { LEW. }\end{array}$ \\
\hline \multicolumn{5}{|c|}{ Little Cross Creek (LCC) } \\
\hline $\begin{array}{l}\text { LCC }-1 \\
\text { LCC }-2 \\
\text { LCC }-3 \\
\text { LCC }-4 \\
\text { LCC }-5\end{array}$ & $\begin{array}{l}\text { Good } \\
\text { Good } \\
\text { Fair } \\
\text { Good } \\
\text { Fair }\end{array}$ & $\begin{array}{l}102.93 \\
103.05 \\
105.97 \\
107.60 \\
107.52\end{array}$ & $\begin{array}{r}615 \\
770 \\
1,565 \\
1,655 \\
1,910\end{array}$ & $\begin{array}{l}\text { Seedline on house } 95 \mathrm{ft} \text { ds bridge, } 75 \mathrm{ft} \text { REW. } \\
\text { Seedline on house } 60 \mathrm{ft} \text { us bridge, } 75 \mathrm{ft} \text { LEW. } \\
\text { Seedline on tree } 45 \mathrm{ft} \text { ds bridge, on REW. } \\
\text { Seedline on power pole } 45 \mathrm{ft} \text { us. bridge, } 200 \mathrm{ft} \text { LEW. } \\
\text { Driftline at base of dam } 100 \mathrm{ft} \text { us. bridge, } 75 \mathrm{ft} \text { LEW. }\end{array}$ \\
\hline $\begin{array}{l}\text { LCC }-6 \\
\text { LCC }-7 \\
\text { LCC }-8 \\
\text { LCC }-9 \\
\text { LCC }-10\end{array}$ & $\begin{array}{l}\text { Good } \\
\text { Excellent } \\
\text { Poor } \\
\text { Good } \\
\text { Poor }\end{array}$ & $\begin{array}{l}118.19 \\
129.89 \\
130.29 \\
137.18 \\
146.02\end{array}$ & $\begin{array}{r}1,980 \\
12,810 \\
13,015 \\
13,360 \\
18,310\end{array}$ & $\begin{array}{l}\text { Seedline on intake wall } 20 \mathrm{ft} \text { us. dam, } 350 \mathrm{ft} \text { LEW. } \\
\text { Seedline on tool shed } 250 \mathrm{ft} \text { ds culvert, } 150 \mathrm{ft} \text { REW. } \\
\text { Mudline on us. culvert headwall. } \\
\text { Seedline on } 4 \text { in. pine tree } 200 \mathrm{ft} \text { us. dam, on shore. } \\
\text { Driftline on LB } 150 \mathrm{ft} \text { ds dam. }\end{array}$ \\
\hline $\begin{array}{l}\text { LCC }-11 \\
\text { LCC }-12 \\
\text { LCC }-13\end{array}$ & $\begin{array}{l}\text { Good } \\
\text { Fair } \\
\text { Fair }\end{array}$ & $\begin{array}{l}160.86 \\
164.62 \\
165.36\end{array}$ & $\begin{array}{l}18,760 \\
23,430 \\
23,535\end{array}$ & $\begin{array}{l}\text { Seedline on } 30 \text { in. pine tree } 300 \mathrm{ft} \mathrm{us.} \mathrm{dam,} \mathrm{LEW.} \\
\text { Seedline on oak tree } 80 \mathrm{ft} \text { ds culvert, } 12 \mathrm{ft} \text { LEW. } \\
\text { Seedline on pine tree } 25 \mathrm{ft} \text { us. culvert, } 10 \mathrm{ft} \text { REW. }\end{array}$ \\
\hline
\end{tabular}

\begin{tabular}{lllr}
\hline EC-1 & Good & 125.19 & 655 \\
EC-2 & Good & 130.69 & 895 \\
EC-3 & Poor & 137.77 & 1,950 \\
EC-4 & Poor & 140.00 & 2,200 \\
EC-5 & Poor & 141.56 & 2,225 \\
& & & \\
EC-6 & Fair & 147.70 & 2,340 \\
EC-7 & Fair & 168.86 & 3,620
\end{tabular}

\footnotetext{
Seedline on oak tree $195 \mathrm{ft}$ ds culvert, $100 \mathrm{ft}$ REW. Seedline on pine tree $45 \mathrm{ft}$ us. culvert, $25 \mathrm{ft}$ LEW. Driftline at REW 350 ft ds culvert.

Driftline on RB $100 \mathrm{ft}$ ds culvert.

Driftine on LB $75 \mathrm{ft}$ ds culvert.

Seedline on oak tree $40 \mathrm{ft}$ us. culvert on $\mathrm{RB}$.

Seedline on large pine tree $70 \mathrm{ft}$ us. spillway, $150 \mathrm{ft}$ left of outflow.
}

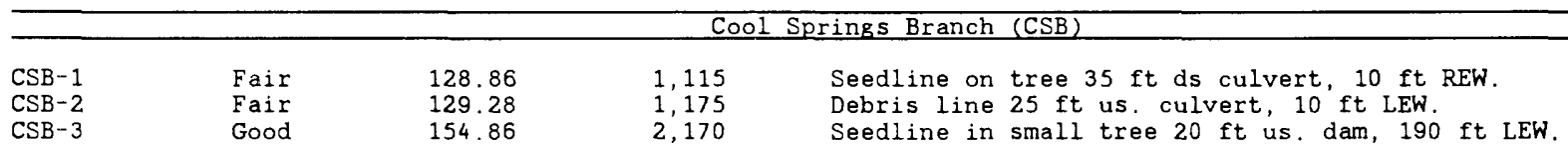

$\begin{array}{lllr}\text { BCC-1 } & \text { Excellent } & 103.05 & 700 \\ \text { BCC-2 } & \text { Excellent } & 103.59 & 850 \\ \text { BCC-3 } & \text { Excellent } & 110.26 & 1,750 \\ \text { BCC-4 } & \text { Fair } & 111.87 & 5,300 \\ \text { BCC-5 } & \text { Good } & 112.60 & 5,650\end{array}$

Seedline on pump station $100 \mathrm{ft}$ ds culvert, $20 \mathrm{ft}$ REW.

Seedline on 4 in. pine tree $50 \mathrm{ft} u s$. culvert, $40 \mathrm{ft}$ REW.

Seedline on $24 \mathrm{in}$. oak tree $50 \mathrm{us}$. culvert, $75 \mathrm{ft}$ REW.

Seedline on 8 in. pine tree $100 \mathrm{ft}$ ds bridge, $50 \mathrm{ft} \mathrm{LEW}$.

Seedline on house $250 \mathrm{ft}$ us bridge, $100 \mathrm{ft}$ LEW. 


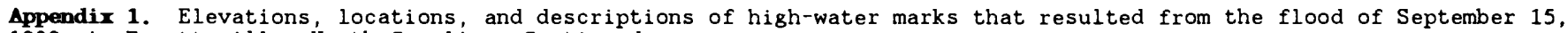
1989, in Fayetteville, North Carolina--Continued

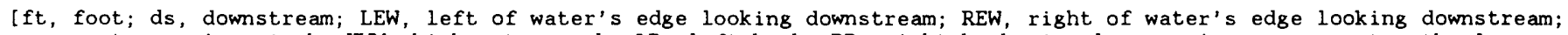
us., upstream; in., inch; HWM, high-water mark; LB, left bank; RB, right bank; \pm , plus or minus; $>$, greater than]

\begin{tabular}{|c|c|c|c|c|}
\hline $\begin{array}{l}\text { High- } \\
\text { water } \\
\text { mark } \\
\text { identi- } \\
\text { fication } \\
\text { number } \\
\text { (pl. 1) }\end{array}$ & Accuracy ${ }^{1}$ & $\begin{array}{l}\text { High- } \\
\text { water } \\
\text { mark } \\
\text { elevation } \\
\text { ( } f t \\
\text { above } \\
\text { sea level) }\end{array}$ & $\begin{array}{l}\text { Distance } \\
\text { upstream } \\
\text { from } \\
\text { mouth } \\
\text { (ft) }\end{array}$ & Description of high-water mark ${ }^{2}$ \\
\hline $\begin{array}{l}\mathrm{BCC}-6 \\
\mathrm{BCC}-7 \\
\mathrm{BCC}-8\end{array}$ & $\begin{array}{l}\text { Good } \\
\text { Good } \\
\text { Poor }\end{array}$ & $\begin{array}{l}130.82 \\
131.08 \\
147.21\end{array}$ & $\begin{array}{l}16,260 \\
16,300 \\
17,870\end{array}$ & $\begin{array}{l}\text { Seedline on } 6 \text { in. willow tree } 40 \mathrm{ft} \text { ds culvert, } 5 \mathrm{ft} \text { REW. } \\
\text { Seedline on left wingwall of road culvert. } \\
\text { Seedline on RB } 100 \mathrm{ft} \text { us. dam. }\end{array}$ \\
\hline \multicolumn{5}{|c|}{ Country Club Branch (CCB) } \\
\hline $\begin{array}{l}C C B-1 \\
C C B-2 \\
C C B-3\end{array}$ & $\begin{array}{l}\text { Good } \\
\text { Good } \\
\text { Fair }\end{array}$ & $\begin{array}{l}124.51 \\
128.61 \\
138.00\end{array}$ & $\begin{array}{r}620 \\
820 \\
3,740\end{array}$ & $\begin{array}{l}\text { Driftline } 30 \mathrm{ft} \text { ds bridge, } 20 \mathrm{ft} \text { LEW. } \\
\text { Seedline on } 30 \mathrm{in} \text {. pine tree } 120 \mathrm{ft} \text { us. bridge, } 25 \mathrm{ft} \text { LEW. } \\
\text { Driftline at } 4 \mathrm{in} \text {. pine tree } 60 \mathrm{ft} \mathrm{ds} \text { culvert, } 30 \mathrm{ft} \text { LEW. }\end{array}$ \\
\hline $\begin{array}{l}C C B-4 \\
C C B-5 \\
C C B-6\end{array}$ & $\begin{array}{l}\text { Poor } \\
\text { Excellent } \\
\text { Excellent }\end{array}$ & $\begin{array}{l}141.93 \\
142.40 \\
145.48\end{array}$ & $\begin{array}{l}3,880 \\
4,150 \\
4,450\end{array}$ & $\begin{array}{l}\text { Driftline on } 3 \text { in. pine tree } 80 \mathrm{ft} \text { us. culvert, } 20 \mathrm{ft} \text { REW. } \\
\text { Seedline on building } 50 \mathrm{ft} \mathrm{ds} \text { dam, } 50 \mathrm{ft} \text { LEW. } \\
\text { Seedline on sundeck } 250 \mathrm{ft} \text { us. dam, } 250 \mathrm{ft} \text { LEW. }\end{array}$ \\
\hline
\end{tabular}

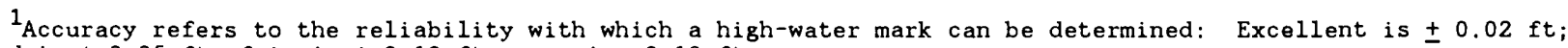
good is $\pm 0.05 \mathrm{ft}$; fair is $\pm 0.10 \mathrm{ft}$; poor is $>0.10 \mathrm{ft}$

2 Distances upstream and downstream are field estimates referenced to centerline of bridge, culvert, road, or dam

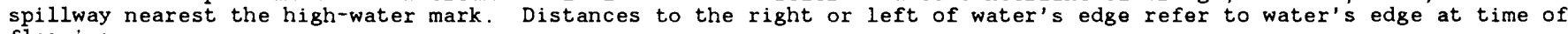
flagging. 


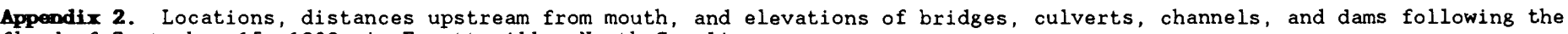
flood of September 15, 1989, in Fayetteville, North Carolina

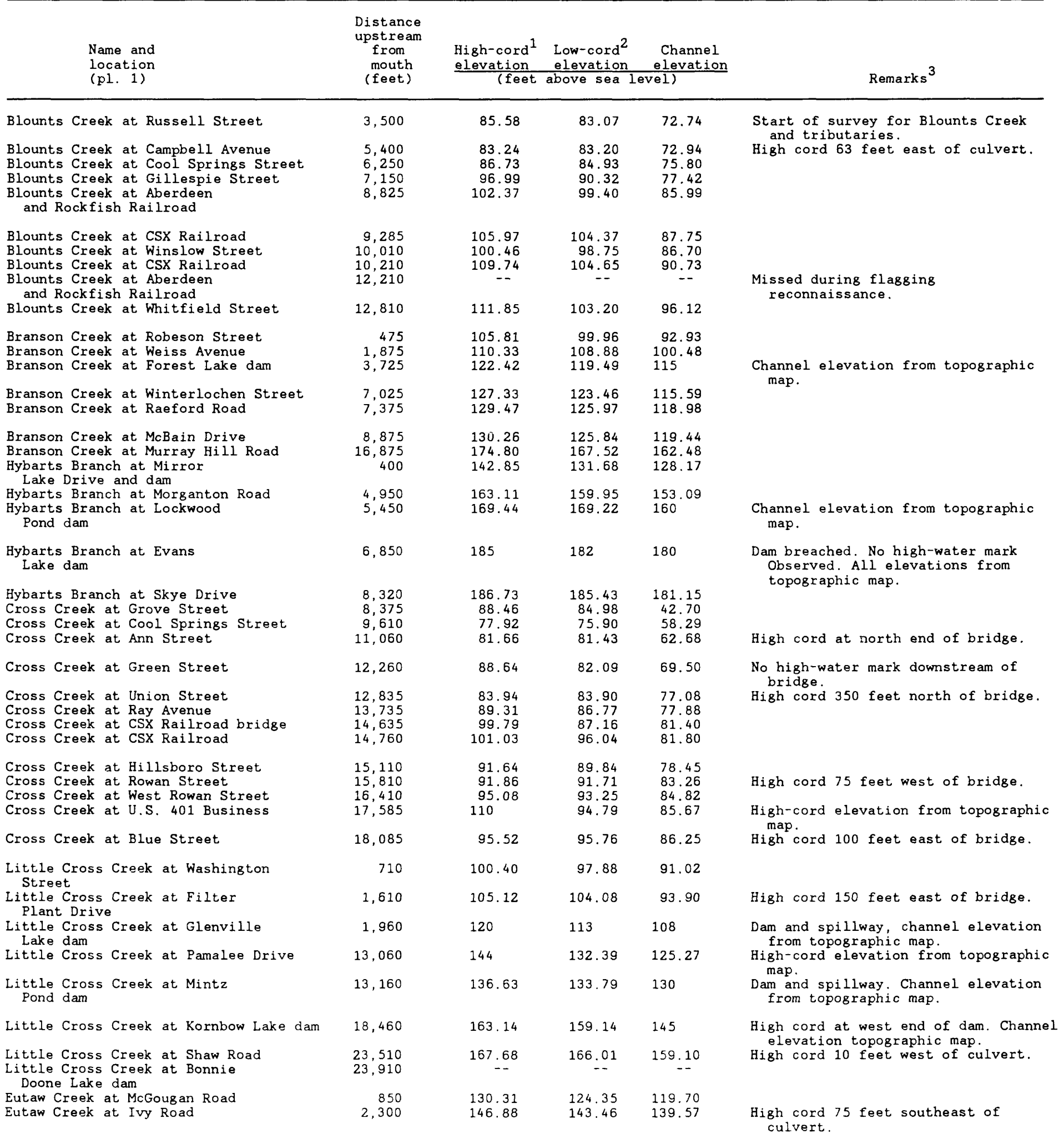




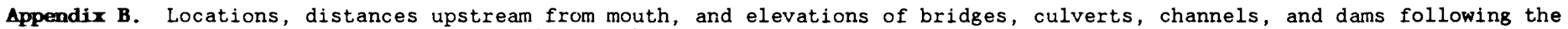
flood of September 15, 1989, in Fayetteville, North Carolina--Continued

[--, missing data]

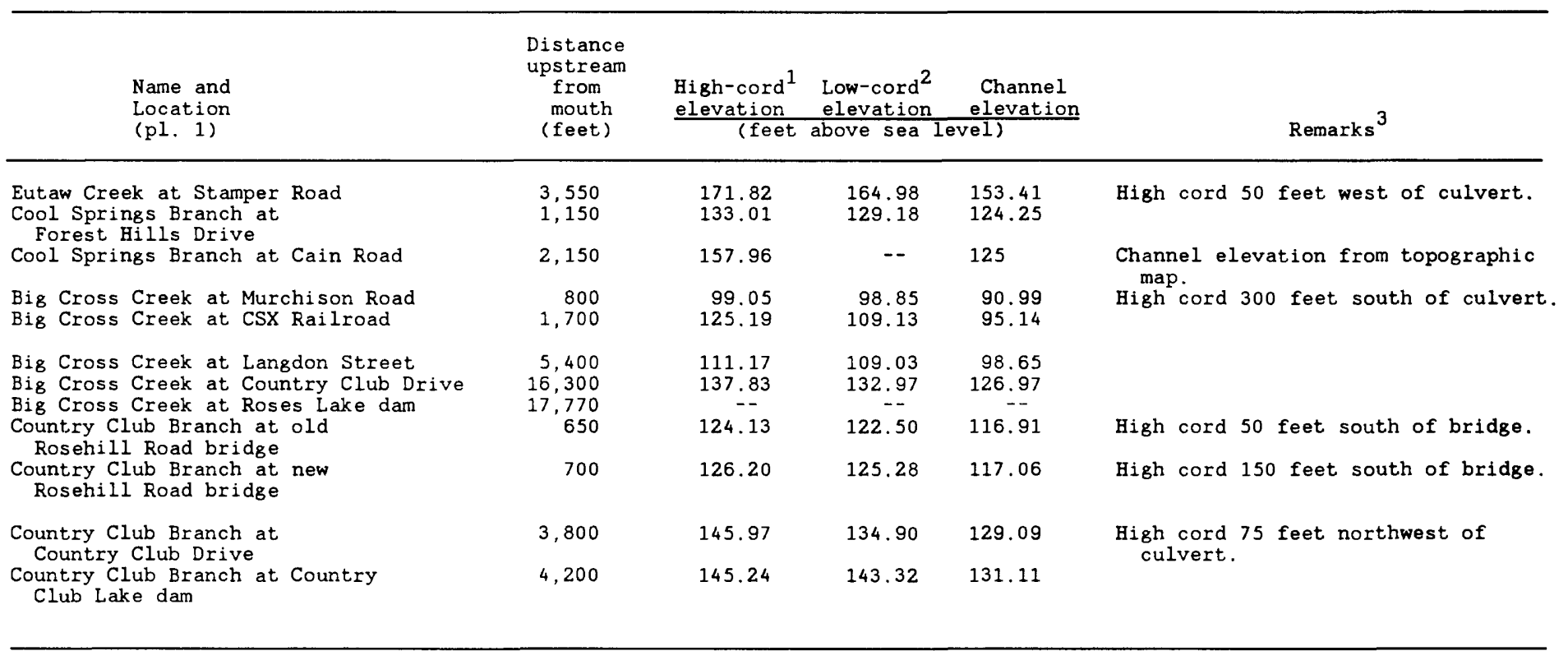

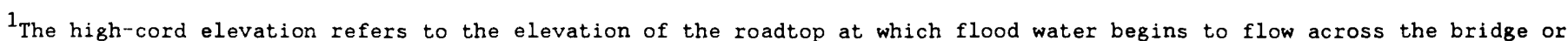

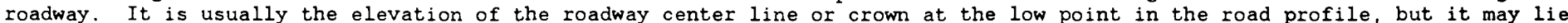

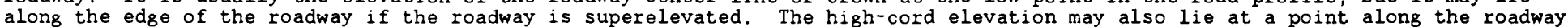

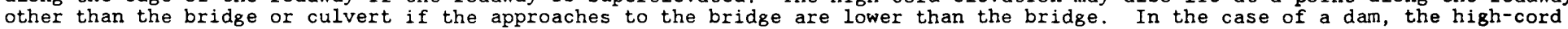
elevation is the elevation at which water begins to flow over the emergency spillway.

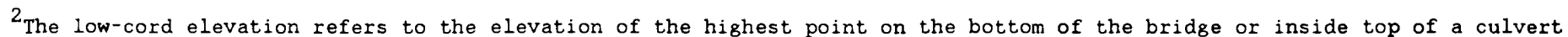

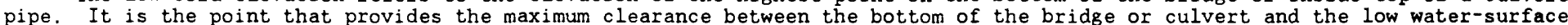
elevation. In the case of a dam, the low-cord elevation refers to the normal spiliway elevation.

${ }^{3} \mathrm{All}$ distances shown in remarks column are field estimates. 